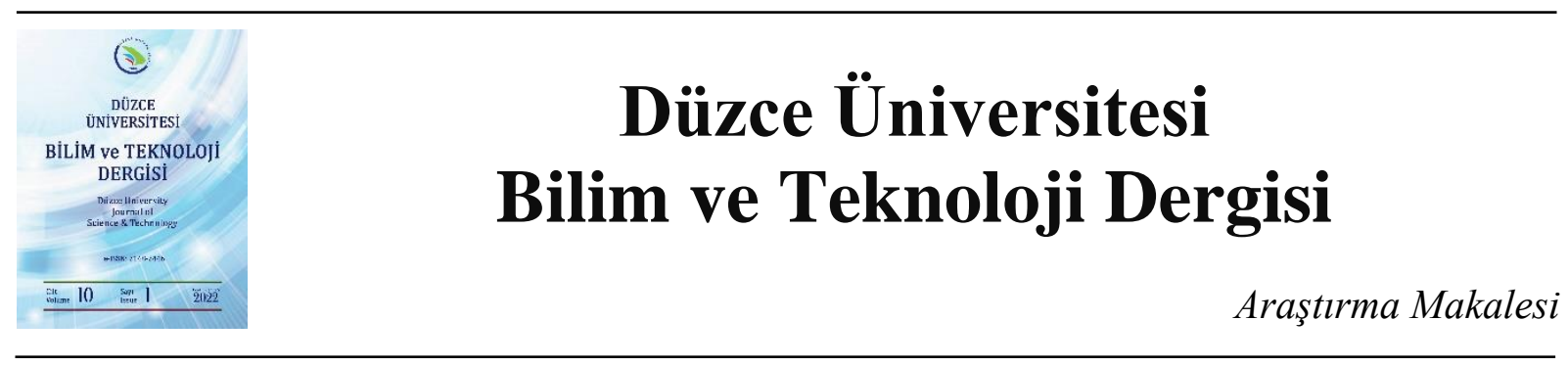

\title{
Su Mimarisi ve Sarnıçlar; Ula Bozyer Sarnıcının Yeniden İşlevlendirilmesi
}

\author{
Murat Erdal DERE ${ }^{\mathrm{a}, *}$ \\ ${ }^{a}$ Dr. Mimar, Muğla, TÜRKIYYE \\ * Sorumlu yazarın e-posta adresi: muraterdaldere@gmail.com \\ DOI: 10.29130/dubited.1027854
}

\begin{abstract}
ÖZ
Suyun insan yaşamının temel ihtiyaçlarından biri olması nedeniyle ilk yerleşimlerin tatlı su kaynaklarının civarında başladığı bilinmektedir. Zamanla şehirlerin büyümesi, su kaynaklarından uzaklaşılması veya mevcut su kaynaklarının yetersiz kalmasıyla suyu yerleşimlere getirme teknikleri gelişmiştir. Yerleşim yerlerine gelen suyu insanların ihtiyacına sunmak ve ihtiyaç fazlasını saklamak için yapılan yapılar su mimarisi kavramıyla tasnif edilmektedir. Su mimarisi, insanın temel ihtiyacı olan suya ulaşmasını, kullanımını ve diğer niteliklerini yansıtan yapılar olarak inşa edilen dönemin kültürü hakkında fikir vermektedir. Bu makale kapsamında suyla ilişkili mimari eserlerin bütüncül bir tasnifi yapılarak, Muğla'nın Ula ilçesindeki sarnıçlar incelenmiştir. Çatı formları itibariyle Küre, Sivri ve Kubbeli, suya ulaşımlarına göre çatı başlangıcında savaklı ve zeminde kapaklı sarnıç tipolojileri tespit edilmiştir. Yerel yönetim kararı ile restore edilerek yeniden işlev kazandırılmak istenen Bozyer Sarnıcı, kubbeli ve çatı başlangıcında savaklı sarnıçlardandır. Makalenin amacı bu sarnıç örneğinden hareketle su mimarisinin tarihte nasıl işlevlendirildiği bilgisi ile birlikte günümüzde yeniden işlev kazandırılarak kültürel mirasa katkı sağlamayı hedeflemektedir. Sarnıçların belgeleme yöntemiyle tipolojileri oluşturulmuş, benzer yapı ve yapıdan gelen iz yöntemiyle Bozyer Sarnıcının restitüsyon ve restitüsyona esas restorasyon projeleri hazırlanmıştır.
\end{abstract}

Anahtar Kelimeler: Mimari, Restorasyon, Sarnıç, Su, Ula.

\section{Water Architecture and Cisterns; Reuse of Ula Bozyer Cistern}

\begin{abstract}
Since water is one of the basic human needs, it is known that the first settlements began near freshwater sources. Over time, techniques for providing water to settlements have evolved as cities grow, move away from water sources, or when existing water resources are insufficient. The structures built to provide the water coming to the settlements for people's needs and to store the surplus are classified with the concept of water architecture. The water architecture gives an idea of the culture of the time, built as structures that reflect the basic need of people to access water, its uses and other qualities. Within the scope of this article, a holistic classification of water-related architectural works has been made and the cisterns in the city of Muğla, Ula district have been examined. Dome, pointed and dome cistern typologies were determined for the roof shapes, depending on the water access, weir at the beginning of the roof and covered cistern on the ground. One of the domed cisterns with a sluice at the beginning of the roof is the Bozyer cistern, which the local government has decided to restore and put back into service. The aim of the article is to use this cistern example to contribute to cultural heritage by making it new functions today, along with knowing how water architecture worked throughout history. The typologies of the cisterns were made using the documentation method, and the restitution and restoration projects of the Bozyer cistern were prepared using the method of traces from a similar structure.
\end{abstract}

Keywords: Architecture, Restoration, Cistern, Water, Ula. 


\section{GIRIS}

Su insan yaşamının temel ihtiyaçlarındandır. Özellikle doğu kültüründe "su", medeniyetin önemli bir unsuru olagelmiştir. Bu unsurun Türk-İslam mimarisi diline tüm çeşitlilikleriyle aktarılmasının sırrı belki de "Hiç içtiğiniz suyu düşündünüz mü?"1 [1] (Esed, 1999, s. 1217) ayetinde saklıdır.

Yerleşim yerlerinin seçimlerinde su kaynakları etkili olmuş, su kaynaklarının yetersiz kalması göçlere neden olmuştur. İnsanlar suyun kaynağına ulaşmak ve kullanmak için yoğun çaba ve emek sarf etmek zorunda kalmışlardır. Suya kavuşmak için çeşitli yöntemler, yollar denenmiştir. Bu ve benzer nedenlerle canlılar için hayati önemi olan su, aynı zamanda yüzyıllardır kutsanmış, kutsallaştırılmıştır. Modern dönemde geliştirilen yöntemlerle suya ulaşmak kolaylaşmış, borularla istenen yerlere taşınmış, evlerin, işyerlerinin içine yerleşmiştir. Emek harcayarak ulaşılan suya, atalarımız kutsallık payesi verirken, günümüzde elimizin altında olan ve emek harcamadan ulaşabildiğimiz su, bizim için ne kadar kutsal olabilir ki? "Su gibi aziz ol" duasıyla atalarımız memnuniyetlerini de su ile dile getirmişlerdir.

Dünya, ölmeden önce içilen bir yudum sudan ibarettir düşüncesine sahip olan atalarımız, suyun kıymetini bilmiş ve bunun için farklı işlevlere sahip mimari mekânlar inşa etmişlerdir. Bu konuyu bütüncül manada Önge; "Yer yüzüne düssen kar ve yağmur sularını sarnıç ve depolarda, mevcut akarsuları bendlerde toplamak, toplanan suları uygun meyillerle kanallar veya tüneller içinde, kemerler üzerinde belli yerlere sevketmek; şehirlere gelen sular mahzenlerden, maslaklardan gereğince terazilerden geçirerek çeşitli yerlere dağıtmak; şehirlerde havuzlar, şadırvanlar, çeşmeler yapmak; alçak seviyelerdeki zemin suların dolaplarla yükseklere çıkartmak; yeraltı sularından istifade için kuyular açmak gibi, çeşitli tesisler, Anadolu'da oldukça eski devirlerden beri düşünülmüş ve tatbik edilmişlerdir." [2] (Önge, Türk Mimarisinde Selçuklu ve Osmanlı Dönemlerinde Su Yapıları, 1997, s. 1) şeklinde özetlemektedir. Bu bağlamda su mimarisi konusunu işleyen kaynaklardan yararlanarak, Türk-İslam medeniyetinin su mimarisi eserlerini kısaca dört ana başlıkta toplamak mümkündür ${ }^{2}$ [15];

1. Suyun membaından şehre getirilmesi için yapılan mimari eserler;

1.1. Su Bendleri (Setleri) (Setler; taş veya kerpiç duvarla suyun toplanması sağlanmıştır.)

1.2. Künkten Su Yolları,

1.3. Su Kemerleri,

1.4. Su Terazisi Yapıları,

2. Temel ihtiyacı karşılamak içim yapılan mimari eserler;

2.1. Sebil,

2.1.1.Bir Külliyenin Parçası olan Sebil,

2.1.1.1. Cephe Sebili,

2.1.1.2. Köşe Sebili,

2.1.1.3. Pencere Sebili,

2.1.2.Müstakil Sebil,

2.2. Çeşme,

2.3. Sarnıç,

2.4. Su Kuyusu,

3. Temizlenme maksadiyla yapılan mimari eserler;

3.1. Hamam,

3.2. Şadırvan,

3.2.1. Sadece Havuzdan İbaret Şadırvanlar,

3.2.2. Üst Örtüsü Sütunlarla Taşınan Şadırvanlar,

3.2.3. Baldaken Şadırvanlar,

3.2.4. Münferit Şadırvanlar,

4. Estetik haz için yapılan mimari eserler, 4.1. Selsebil;

\footnotetext{
${ }^{1}$ Vakı'a Suresi 68 ayet meali

${ }^{2}$ Ula Bozyer Sarnıcı projesi kapsamında su mimarisine ilişkin literatürün taranması sonucunda yapılan tasniftir.
} 
4.1.1.Basamakl1 Selsebil,

4.1.2. Aynalı Selsebil,

4.1.3. Rampal1 Selsebil,

\subsection{Havuz.}

Suyun membaından şehre getirilmesi için yapılan mimari eserler; yerleşimler her ne kadar suya yakın kurulsalar da ahalinin suya ulaşımı zamanla ciddi bir sorun teşkil etmiştir. Şehir nüfusunun büyümesiyle şehir genişlemiş ve doğal olarak suya, su miktarına duyulan ihtiyaç artmıştır. İnsanın temel ihtiyacı olan suyu başka kaynaklardan karşılamak için önce "su bendleri" [3] (Arseven, 1984, s. 96) (su setleri-baraj; suyun toplanması amaciyla), bu bendlerden şehre ulaşacak su yolları inşa edilmiş ve suyun cazibeli şekilde şehre ulaşımı sağlanmıştır. Suyun akışını sağlamak, tepeler arasında istenilen eğim oranı ve akış hızını arttırmak için günümüzde de gördüğümüz su kemerleri inşa edilmiştir. Su kemerleri ve su yolları ile şehre gelen suyun şebekeye ulaşımını sağlamak ve suyun basıncını ayarlamak için su terazi yapılarına ihtiyaç duyulmuş ve inşa edilmiştir. Böylelikle su tedarik zincirleri tamamlanmış mahalle başlarına hatta evlere dek su getirilmiştir.

Temel ihtiyacı karşılamak için yapılan mimari eserler; sebil, çeşme, su kuyusu ve sarnıç olmak üzere dört ana başlıkta toplanmıştır.

Sebil; Anadolu coğrafyasında genelde büyükşehirlerin önemli meydanlarında halkın ihtiyaçlarına yönelik hayırseverlerin inşa ettirdikleri ve içinde su dağıtan insanların bulundukları büyük çeşmelerdir. Sebiller, inşa edildiği dönemin mimari üsluplarını ve bezemelerini doğal olarak yapıya yansıtmışlardır. Sebiller ya bir külliyenin parçası ya da bağımsız yapı olarak inşa edilmişlerdir. Bir külliyenin parçası olarak inşa edilen sebiller, konumlarına nispetle adlandırılmışlardır. Bunlar; bir cephe içine konumlandırılmışsa "cephe sebili" [4], köşeye konumlandırılmışsa "kösse sebili" [4] veya bir cephe içinde sadece pencere açıklığ Ayrıca önemli merkez ve caddelere bir külliyenin parçası olmadan müstakil yapı olarak da inşa edilmişlerdir. Sebiller plan tipleri itibariyle; yuvarlak, yarım daire ve çokgen planlı tasarlanmış ve üzerleri geniş saçaklı kubbeyle örtülmüştür. Kubbeyi taşıyan sütun ya da taşıyıcı ayakların arası ise; "bronz yahut mermer şebekeler, kornişler, kitabeler ve saçaklardan meydana gelir." [4] (Urfalığlu, 2009, s. 250).

Çeşme; çeşme kelimesini Celal Esad Arseven şöyle tarif etmektedir: "Su kaynağı manasında Türkçede göz kelimesinin Farsça karşıllğ̆ olan çeşim sözünden alınmıştır. Kaynağından bir hazneye toplanarak veya borularla getirilerek akıtılan suların alınmasına mahsus lüleli veya musluklu bir hazne şeklinde mermerden, taştan veya sair malzemeden yapılmış umuma mahsus su alma yeri." [5] (Kızılkayak, 2011, s. 20) şeklinde tanımlamaktadır. "Türk sanatının çeşitli dönemlerine ait çeşmeleri mimari özellikleri yanı sıra taş iş̧̧iliği ile süslenmiş mermer veya taş kaplamalarıyla önem taşırlar. " [6] (Barışta, 1995, s. IX). Çeşmelerin Türk yapı sanatlarında ayrı bir yeri vardır. "Özellikle Osmanlı döneminde şehir dokusunun en elverişli yerinde inşa edilen ve halkın su ihtiyacını karşılamayı amaçlayan çeşmelerde: Hem yararlı olma niteliği göz önünde tutulmuş hem de estetik değerler sergilenmiştir." [6] (Barışta, 1995, s. IX). Bu konuyu Prof. Dr. Sadettin Ökten kısaca; "Eskiden İstanbul sokağının bir yerinde mutlaka bir akar çeşme vardl. Kitabesinden suyun ardındaki manevi değer ve hikmeti ögrenir, lülesinden de serin suyun kendisinden faydalanma imkânınız olurdu. Yalakta biriken suları ise eski İstanbul'un ayrılmaz bir parçası olan diğer canlılar, mesela kuşlar içerdi." [7], (Ökten, 2019, s. 154) şekilde özetlemektedir.

Temizlenme maksadiyla yapılan mimari eserler; hamam ve şadırvan olmak üzere iki ana başlıkta toplanmıştır.

Hamam Roma döneminde ortaya çıkmış, Müslümanların Suriye bölgesini Romalılardan fethiyle, Roma hamamlarıyla tanışılmıştır. Başta Araplar sonra da Türkler, Roma hamamının temel prensiplerine dokunmadan kendi yorumlarıyla yeni bir hamam türü ortaya çıkarmışlar ve bu hamamlar Avrupa'da “Türk Hamamı" olarak adlandırılmıştır. Roma hamamı ile Türk hamamı arasındaki temel fark; birinde havuz ve küvet içine su doldurulurken, diğerinde havuz ve küvet olmayıp suyun cazibeli bir şekilde 
çeşmeye ve çeşmeden de kurnaya akmasıdır. Ayrıca Türk hamamında göbek taşı olması diğer ayırt edici bir özelliktir. Bu özelliği Arseven; "Sıcaklığın müşterek kısmının ortasında ya çember ya da sekizgen biçiminde yüksekçe kerevet vardır, yıkanacakların terlemek ve vücutlarını ovdurmak için uzandıkları, genellikle epey sicak olan bu yere göbek taşı denir." [3] (Arseven, 1984, s. 102), şeklinde tanımlamaktadır.

Şadırvan; genellikle cami avlusu içinde bulunan, çevresindeki musluklardan ve ortasındaki fıskiyeden su akan üzeri açık veya kubbeli abdest alma yeridir. Genel olarak her camide bulunur. Şadırvanın ortasındaki havuzu, estetik bir kubbe örtüsü kaplar ve sütunlarla çevrilidir. Altıgen veya sekizgen yapıyı çevreleyen saçakların altında musluklar bulunur, oturaklar taş veya ahşaptandır. Bunun haricinde Edirne Eski Cami'sinde olduğu gibi bazen tek sıra halinde düz de olabilir. Ali Kılıcı, şadırvanları; "Havuzdan ibaret, Üst Örtüsü Havuz Köşelerine Yerleştirilmiş Sütunlarla Taşınan, Baldaken ve Münferit" [8] (Kılc1, 2010, s. 220), olmak üzere dört ana başlıkta toplamıştır.

Estetik haz için yapılan mimari eserler; selsebil ve havuzlardır. Selsebil; "Arapça 'tatlı su' manasına gelen ve cennette bir pınarın adı olan selsebil kelimesinin Kur'an-ı Kerim 'de ${ }^{3}$ [1] geçtiği söylenir. " [9] (Ünver \& Önge, 1981, s. 339). Doğada bulunan çağlayan, şelale veya pınardan esinlenerek inşa edilen selsebiller, alt alta yerleştirilmiş küçük havuzcuklardan meydana gelip, üsten gelen suyun kendi içindeki haznesini doldurup kenarlarından taşarak veya belli deliklerden akarak bir alttakini doldurmasıyla hem görsel hem de işitsel bir oyunla insana haz veren mimari öğelerdir.

Selsebillerin merdivene benzer kademeler biçimde yerleştirilmiş düzeneğe "Basamaklı Selsebil" [10] denir. Bu tarz selsebillerin en güzel örneğini Topkapı Sarayı XVI. yy. Sultan III. Murad Köşkünde bulunmaktadır. "Aynalı Selsebil" [10]; kemerli bir niş içine yerleştirilmiş şakuli bir mermer pano üzerinde simetrik tertipte yer alan konsol biçimindeki çanakçıklardan oluşan sebillerdir. Suyun yüksek bir noktadan başlayarak eğimli bir rampadan akış hızı ayarlanarak bir havuzda toplanması tarzında inşa edilenlere "Rampall Selsebil" [10] (Tanman, 2009, s. 449), denir.

Havuzlar; saray veya özel bahçeleri süslemek amacıyla yapılan havuzlar, fıskiyeli ve fiskiyesiz olarak iki ana başlıkta toplanabilir. Avrupa'nın birçok şehir meydanlarında fiskiyeli havuzlara rastlamak mümkündür. Kültürümüzdeki havuzlar ister fıskiyeli isterse fiskiyesiz olsun saray veya konak bahçelerinin merkezine konumlanmış, seyir zevki vererek dinlendiren mimari öğelerdir. Bahçeler haricinde avlusu olan medrese, han veya hamamların soyunmalık kısımlarının merkezine konumlandırıldıklarına sıkça rastlanmaktadır.

\section{SARNIC}

Geniş İslam coğrafyasında ihtiyaç duyulan her yerde, özellikle ticaret ve hac kervan yolları üzerinde belli aralıklarla sarnıçlar bulunduğuna işaret eden Bozkurt, sarnıcı yağmur suyunu biriktirip saklamak, temiz ve tatlı su ihtiyacını karşılamak için inşa edilmiş su deposu yapıları şeklinde tarif etmektedir. Bozkurt devamla; "Sarnıç kelimesi, "su depolamak üzere yapılmış üstü kapalı veya açık havuz" anlamindaki Arapça sihrîcden (çoğulu sahârîc) gelmektedir.” [11] (Bozkurt, 2008, s. 158), şeklinde etimolojik olarak mana vermektedir. Yaptığımız araştırmalarda sarnıç üzerine yazılmış ilk eser Yılmaz Önge'ye aittir. Önge, makalesinde; "Sarnıçlar, toprak sathındaki yağmur ve kar sularını toplamak için yapılmış üzeri açık veya kapalı havuzlardır. Toprak derinliklerindeki sular da kuyular vasıtasıyla toplanır. Tetkik edebildiğimiz sahadaki kapalı sarnıçlar, suyun toplandiğı kare veya dikdörtgen planlı bir havuz ile bunun üzerini örten, moloz taştan inşa edilmiş bir kubbe veya tonozdan ibarettir." [12] (Önge, 1967, s. 24), diyerek sarnıcı havuz üzeri örtülü yığma taş mekândan ibaret şeklinde tarif etmektedir. A. Şevki Duymaz ise sarnıçların çatılarının değişik geometrik formlarından hareketle; "Sarnıçların kendine özgü bir mimari şekli olup, bu şekil aslında suyun daha kolay toplanması amacıyla

\footnotetext{
${ }^{3}$ İnsan Suresi 17-18 ayet meali; "Ve [cennette] kendilerine zencefille tatlandırılmış bir fincan içecek verilecek, oradaki 'Selsebil' isimli bir kaynaktan"
} 
ortaya konulmuştur. Kubbeli, tonozlu, konik külahll, yayvan ve düz çatıll üst örtü formlarlyla suyun daha kolay bir şekilde toplanmasina imkân verir." [13] (Duymaz, 2009, s. 226), diyerek çatı formlarının yağmur suyunun bulunduğu mevkiinin yağış şekline göre sarnıç haznesine akışının kolaylaştırmasından bahsetmektedir.

Bir binanın unsuru olarak özellikle şebeke suyu gelişiminden önce, evlerin bodrum katlarında küçük sarnıçlar yapılır ve bu sarnıçlarda, damdan (çatı) oluklarıyla bodrum katına indirilen yağmur suları, kullanılmak için biriktirilirdi. Daha eski dönemlerde ise, suyu bir mahalle ya da şehir halkı tarafından kullanılmak üzere, çok daha büyük boyutlarda sarnıçlar yapılırdı (İstanbul Yerebatan Sarnıcı, Beçin İç Kale Sarnicı vs.).

Muğla ilindeki sarnıçların bir kısmı kitabeleriyle günümüze ulaşmıştır. Bu kitabelerden yapıların inşa edildiği tarih ve banisi hakkında bilgi edinilebilmektedir. Açıkgöz'ün Muğla yöresinde yaptığı araştırmalarda Bodrum-Güvercinlik arasında yolun deniz tarafinda konumlanan ve kitabesinde Hasbüna'llah ve ni'me'l-vekil ni'me'l-Mevla ve ni'me'n-nasir-Sahibü'l hayrat ve'l-hasenat El-Hacc Abdullah el-Muğlavi-Sene 1180 (Miladi 1766) bilgisi yer almaktadır [14] (Açıkgöz, 2005, s. 19).

\section{A. SARNIÇLARIN TASNIFI}

Sarnıçların inşa edilme tipolojisine göre; oyma, gömme ve kısmi gömme, sarnıçlar olmak üzere üç ana başlikta toplayarak tasnif etmek mümkündür.

Şekil 1 (a), (b) ve (c) görüldüğü gibi kayayı oyarak elde edilen sarnıç tipleridir. Oyularak oluşturulan su haznesi kışın yağan kar ve suyla dolmaktadır. Kışın suyla dolan bu sarnıçlar yaz aylarında kullanılmaktadır. Bu sarnıçlara "Oyma" sarnıcı şeklinde adlandırılabilinir [15].

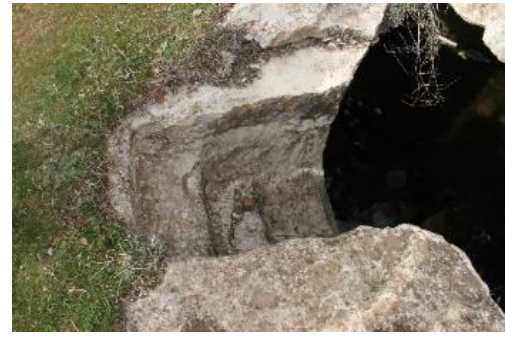

(a)

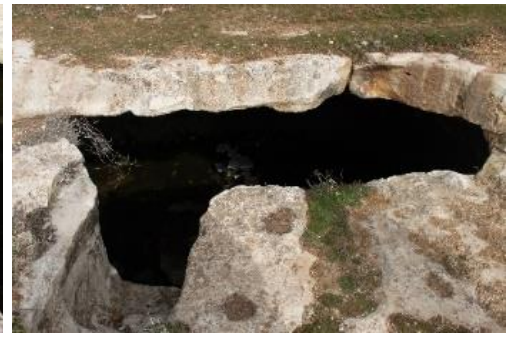

(b)

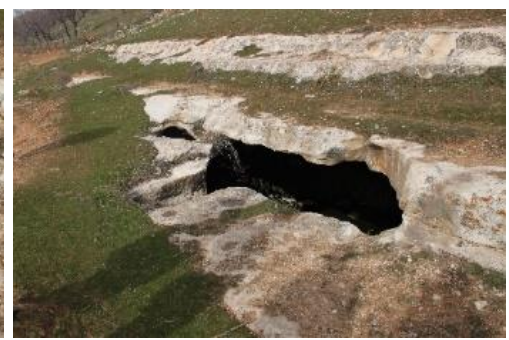

(c)

Şekil 1. Kayayı Oyma şeklinde yapılan Sarnıç, Tillo-Siirt (Fotoğraf; M.E. Dere)

Özellikle yerleşim yerlerinde zeminin oyularak oluşturulan çukurun etrafı taş veya tuğla malzemeden örülerek ve üzerleri su geçirimsiz harçla sıvandıktan sonra üzeri genelde tonozla kapatılarak elde edilen sarnıçlara da Şekil 2 (a) ve (b) görüldüğü gibi "Gömme" sarnıçlar şeklinde kavramlaştırılabilinir [15]. Bu sarnıçların hazneleri yağmur sularıyla beslenmektedir.

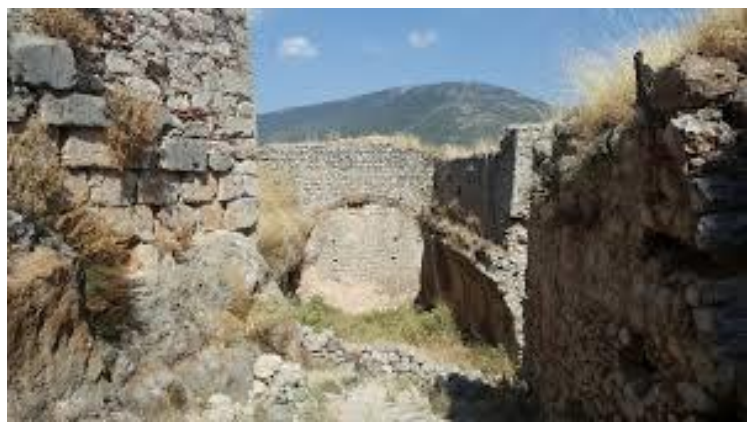

(a)

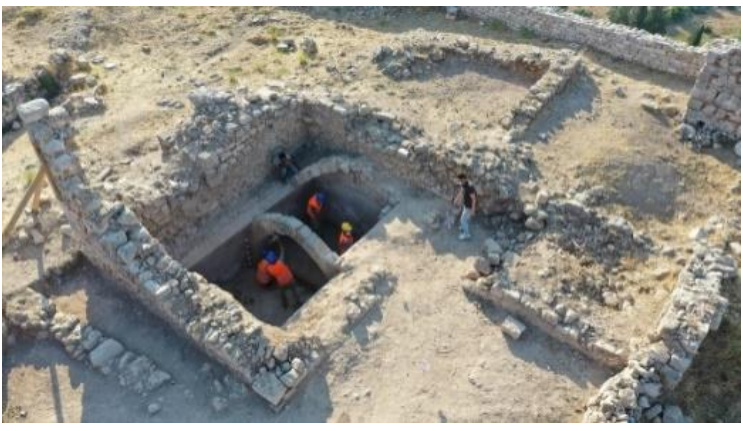

(b)

Şekil 2. Beçin İç Kale:(a) girişteki büyük Sarnıç- (b) bir evin altında küçük Sarnıç (Fotoğraf; M.E. Dere) 
Zemine kısmi olarak gömülen sarnıçlar ise Muğla yöresinde sık rastlanan sarnıç çeşidi olup araştırma konusu olarak aşağıda detaylı şekilde işlenmiştir.

\section{B. ULA YÖRESİ SARNIÇ YAPILARININ TASNIFI}

Plan olarak dairesel formda olup, "Kısmi Gömme Sarnıç" kategorisinde yer alırlar. Zemin kısmi olarak açılır, etrafı harçlı moloz taş ile silindirik formda örülür ve içleri su geçirimsiz horasan harcıyla sıvanarak suyun haznede kalması sağlanır. Gömülü kısım ise hazne yüksekliğinde olup yaklaşık 2,00 m civarındadır. Böylelikle toprağın 1sı yalıtım özelliğinden faydalanılarak hem suyun dinlenmesi hem suyun sıcaktan bozulmaması hem de yaz mevsiminde suyun serin kalması sağlanmaktadır. Sarnıçların mutlaka dışa açılan bir kapıları ve haznesinin zeminine dek inen taş merdivenleri bulunmaktadır [15].

\section{B. 1. Çatı Formları İtibariyle Sarnıçlar}

Ula yöresinde, mevcut sarnıçlar kısmi gömme sarnıçlar olup, yaptığımız incelemeler sonucunda çatı formları bağlamında birbirlerinden ayrıştıkları gözlenmiştir. Sarnıçların tasnifini ise çatı formlarına göre; Şekil 3'tekine "Sivri”, Şekil 4 ve 5'tekine "Kubbeli" ve Şekil 6'dakine "Yüksek Kubbeli", sarnıçlar olmak üzere üç başlıkta toplamak mümkündür. Muğla Yatağan yöresi sarnıçlarını incelemiş olan Kundurac1; "Muğla çevresindeki bu sarnıçların daha çok kubbeli üst örtüsünden dolayı Gümbet ismi ile tanındıkları ögrenilmiştir.” [16], şeklinde başka bir tanımlama getirilmektedir.

Bu tasnifin "Sivri Kubbeli Sarnıcına" örnek teşkil eden (Şekil 3), Ula-Yeşilova (eski Çaydere) yolu üzerinde ve tapunun; Muğla ili, Ula ilçesi, Alparslan Mahallesi, Kabacapınar Mevkiinin, 78 Ada, 10 Parselinde ki mevcut sarnıçtır [15].

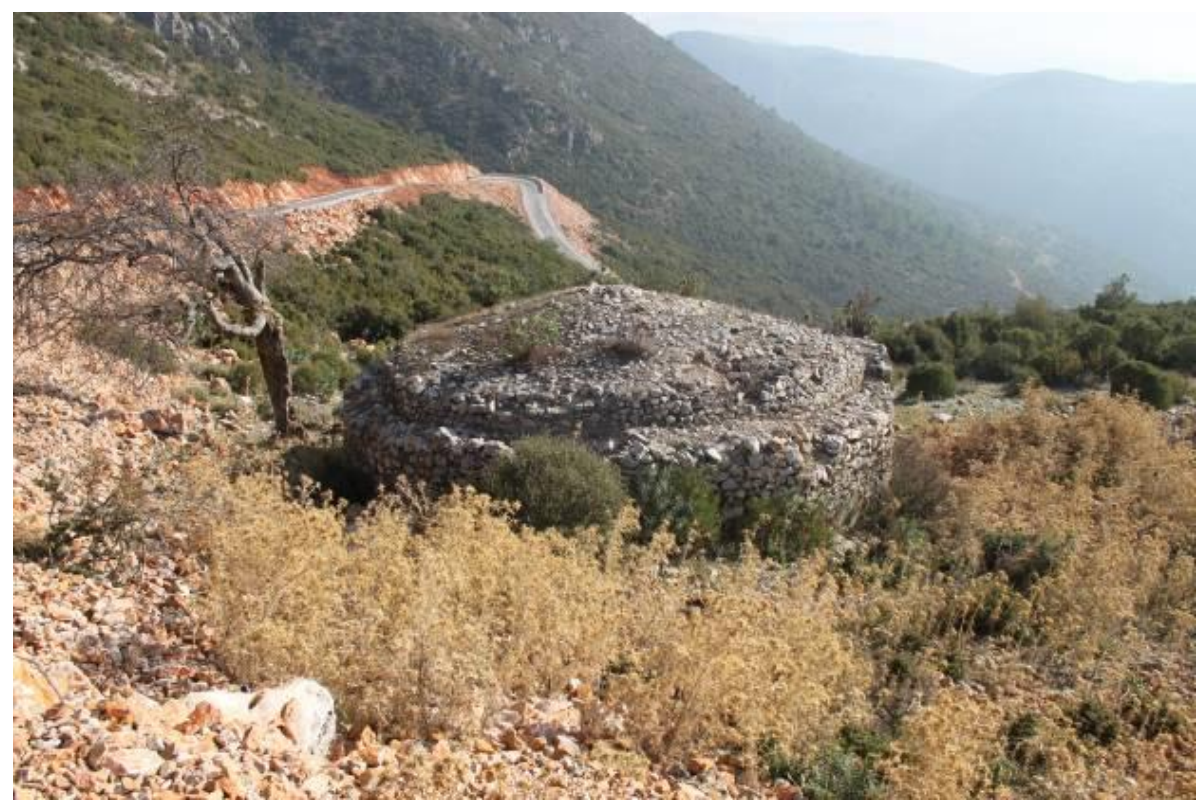

Şekil 3. Sivri Kubbeli Kabacapınar Sarnıcı (Fotoğraf; M.E. Dere)

Kubbeli Sarnıca (Şekil 4) ise, yine aynı yol güzergahı üzerinde mevcut Yeşilova yol kavşağındaki (eski Çaydere) tapunun; Muğla ili, Ula ilçesi, Yeşilova Mahallesi, Çaydere Mevkiinin, 45 pafta, 79 ada ve 40 Parselindeki sarnıç örnek teşkil etmektedir [15]. 


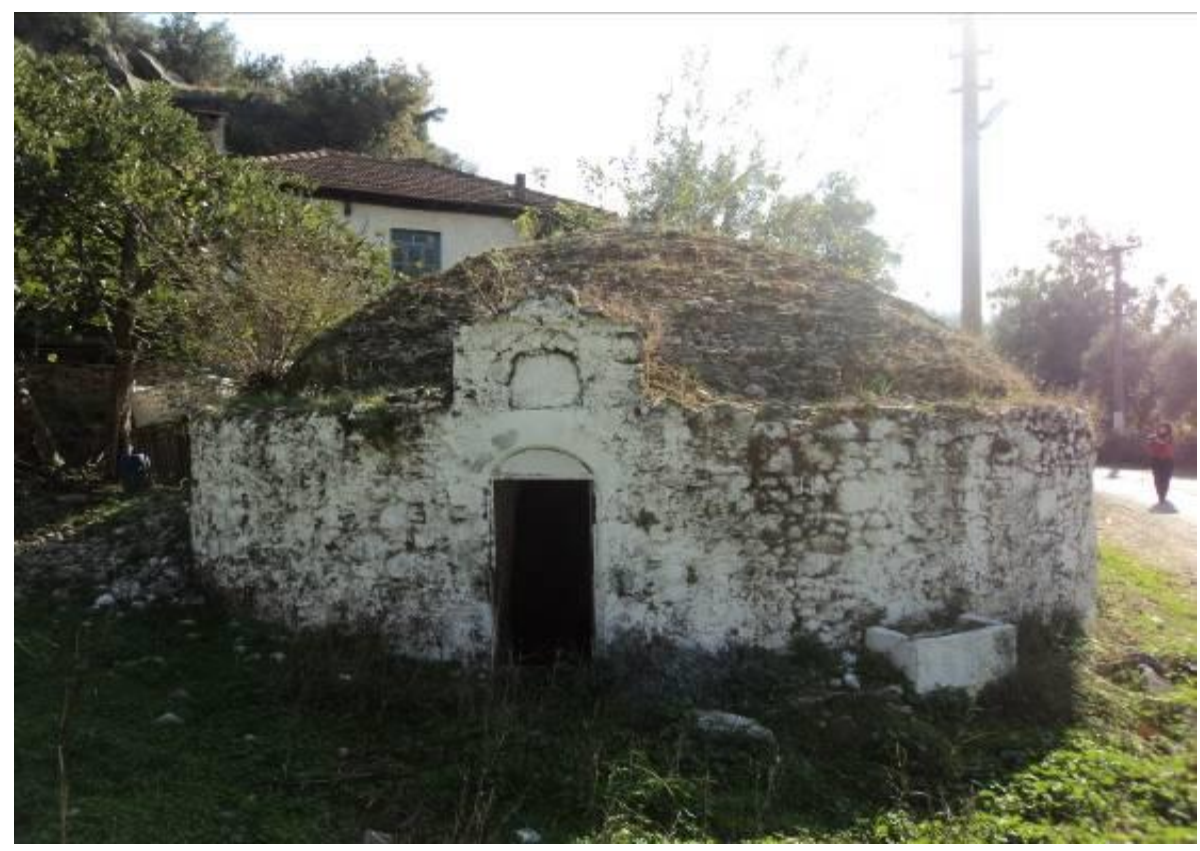

Şekil 4. Kubbeli Çaydere Sarnıcı (Fotoğraf; M.E. Dere)

Kubbeli Sarnıcına bir başka örnek ise; Ula İlçesi, Demirtaş Mahallesi, Kızılcaekin Mevkii, 35 pafta, 43 ada, 2 parselde yer alan Kızılcaekin Sarnıcı (Şekil 5), Ula ile eski Çaydere Köyünü (günümüzde Yeşilova mahallesi) bağlayan yol üzerindedir [15].

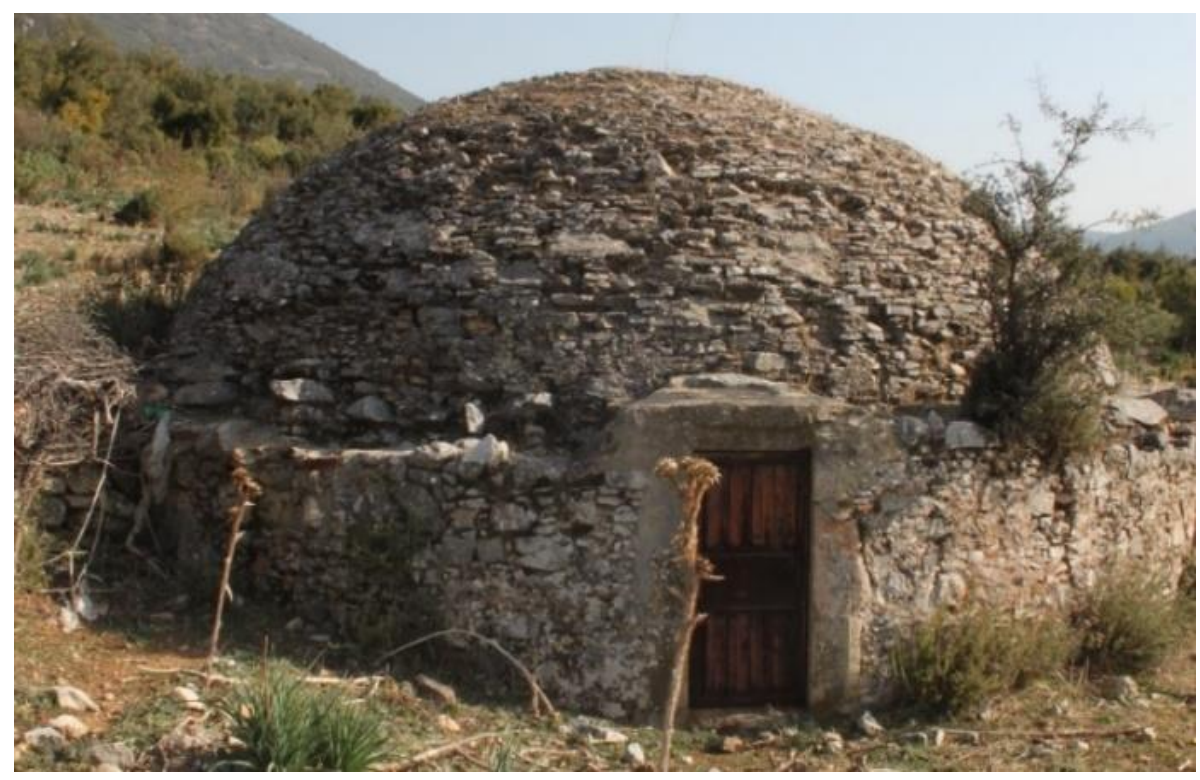

Şekil 5. Küre Kubbeli Kızılcaekin Sarnıcı (Fotoğraf; M.E. Dere)

Yüksek Kubbeli (Şekil 6) Sarnıcına ise, Gökova köyünün Kozlukuyu mevkiinde yer alan, tapunun; Muğla ili, Ula ilçesi, Gökova Mahallesi, 173 Ada ve 8 Parselindeki sarnıç örnek teşkil etmektedir [15] 


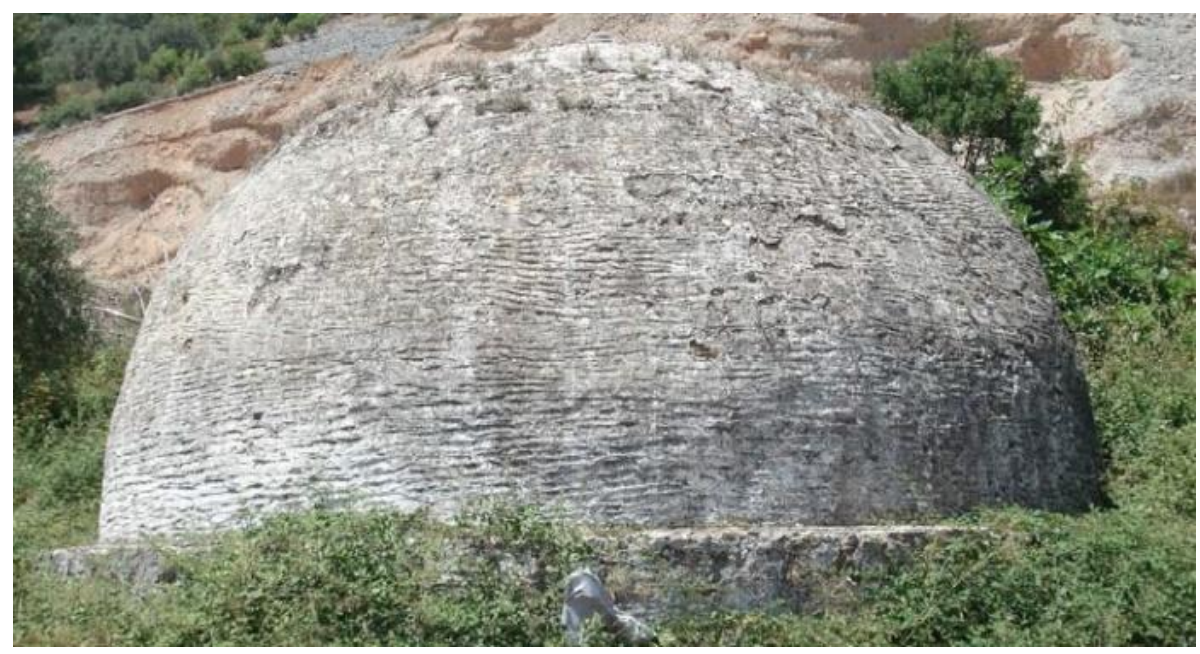

Şekil 6. Yüksek Kubbeli Gökova Sarnıcı (Fotoğraf; M.E. Dere)

\section{B. 2. Sarnıçların Suya Ulaşmalarına Göre}

Yaptığımız çalışmalar ve incelemeler sonrasında Ula yöresinde mevcut sarnıçların su haznelerinin dolumu iki şekilde sağlanmaktadır. Bunları; "zemininden kapaklı" ve çatı başlangıcında "savaklı" sarnıçlar, şeklindeki tasnif etmek mümkündür. Bunlardan zemininde kapağı (deliği) olanlar (Şekil 7a) yanlarında dere veya akarsu olan sarnıçlardır ki, su haznelerinin dolumu, akan sudan açılan su arkı yardımıyla ve zeminde açılan kapak (delik) sayesinde olmaktadır. Bu delikler (kapaklar) yerine göre bir ya da iki adettir [15].

Akarsu veya dereye yakınlığı olmayan sarnıçlar ise yağmur sularıyla dolan sarnıçlardır. Bu sarnıcın haznesinin dolumu ise, kubbeli çatılardan süzülerek inen suyun, silindirik formdaki beden duvarının bitimiyle, çatı başlangıçlarında açılan savaklardan (delikler) (Şekil 7b) akıp toplanmasıyla sağlanmaktadır. Ayrıca silindirik beden duvarlarının bittiği hiza içe doğru eğimli olup çatıdan beden duvarına doğru akan suların savaka ulaşması, oradan da iç hazneye dökülüşü sağlanmaktadır [15].

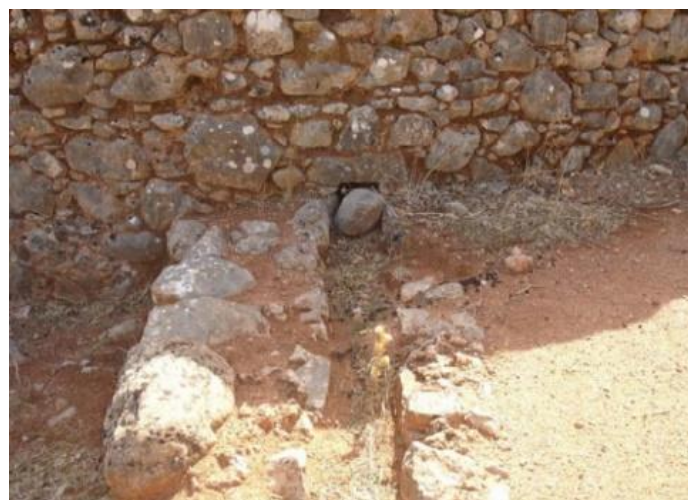

(a)

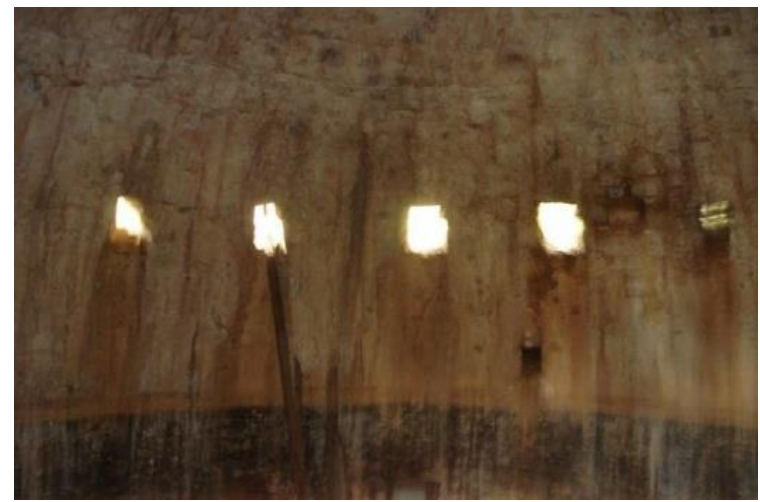

(b)

Şekil 7. (a) Haznesi dışarıdan su arkı ile dolan Sarnıç tipi örneği (b) Savaklarla içine yağmur suyunu haznesinin dolmasını să̆layan Sarnıç tipi örneği (Fotoğraf; M.E. Dere)

Özetle; yöredeki sarnıçların, Muğla-Ula yol güzergahlarında ve belirli mesafelerde kısmi gömme şeklinde yer üstünde inşa edildikleri ve dairesel plan şemasına sahip oldukları görülmektedir. Söz konusu yörenin; su kaynağından veya sadece yağmur suyu ile beslenen iki ayrı tip sarnıca rastlanmıştır. Kubbe kasnağının başlangıcında savak denilen açıklıklarla yağmur suyun sarnıcın içine akışı sağlanmış, diğerinde toprak seviyesindeki beden duvarındaki açıklıktan yararlanılarak su depolanmıştır. 
Sarnıçlarda kapı açıklı̆̆ından iç mekâna, taş basamaklı merdivenlerle de hazneye ulaşım sağlanmaktadır.

\section{ULA BOZYER SARNICI}

\section{A. KONUMU}

Ula, Muğla'nın antik dönemlere kayıtlanan eski yerleşimlerinden ve günümüzün 13 ilçesinden biridir. İlçenin tarihi konusunda Eroğlu; Atina'da yapılan bir kazıda ortaya çıkan kitabede, M.Ö. 440 yıllarında kurulan İyon birliğine bağlı Karya şehirleri arasında Ola adının yer aldığını ayrıca Kanuni Sultan Süleyman'ın Rodos seferi dönüşü 7 Ocak 1523'te ordugahını Ula'ya kurduğu bilgisini Rodos seferi kayıtlarına dayanarak vermektedir [17] (Zekai Eroğlu, 2011, s. 169).

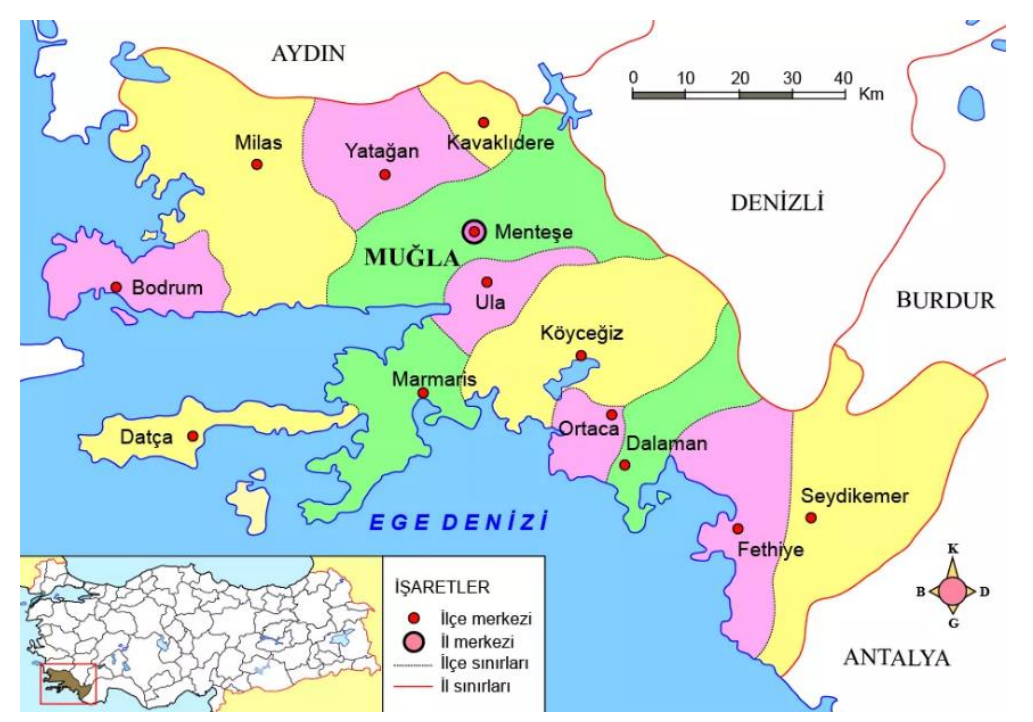

Şekil 8. Muğla il sinırı ve ilçeleri [18]

Bozyer Sarnıcı, Muğla İli, Ula İlçesi (Şekil 8), Alparslan Mahallesinin Bozyer Mevkiinde yer alan ve

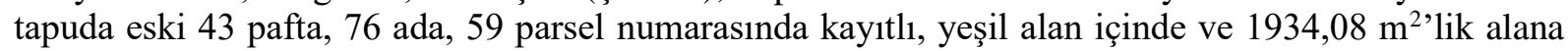
sahip olup (Şekil 9) Belediye mülkiyetindedir. Muğla Kültür Varlıklarını Koruma Bölge Kurulu'nun 24.06.2005 tarih ve 951 sayılı kararı ile de tescillenmiştir [19].

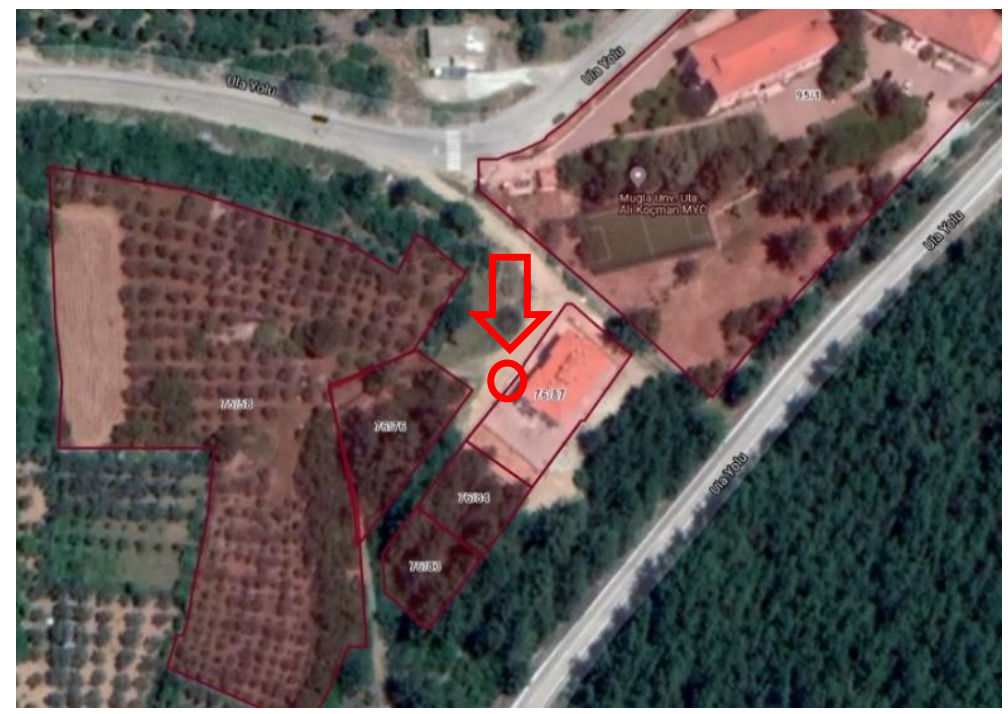

Şekil 9. Sarnıç Vaziyet ve çevresindeki Mülkiyetler [20] 
Bozyer Sarnıcı (Şekil 9-10); kuzey ve doğusu yolla çevrilidir. Sarnıcın kuzeyinde Muğla Sitkı Koçman Üniversitesi Ula Ali Koçman Meslek Yüksek Okulu, doğusunda 76 Ada 87 parsel üzerinde özel mülkiyetli Apartman, güneyinde yine 76 Ada ve 76 parselli imarlı arsa ve batısında da 75 ada, 58 parsel tarla nitelikli mülkiyetlerle çevrilidir [15].

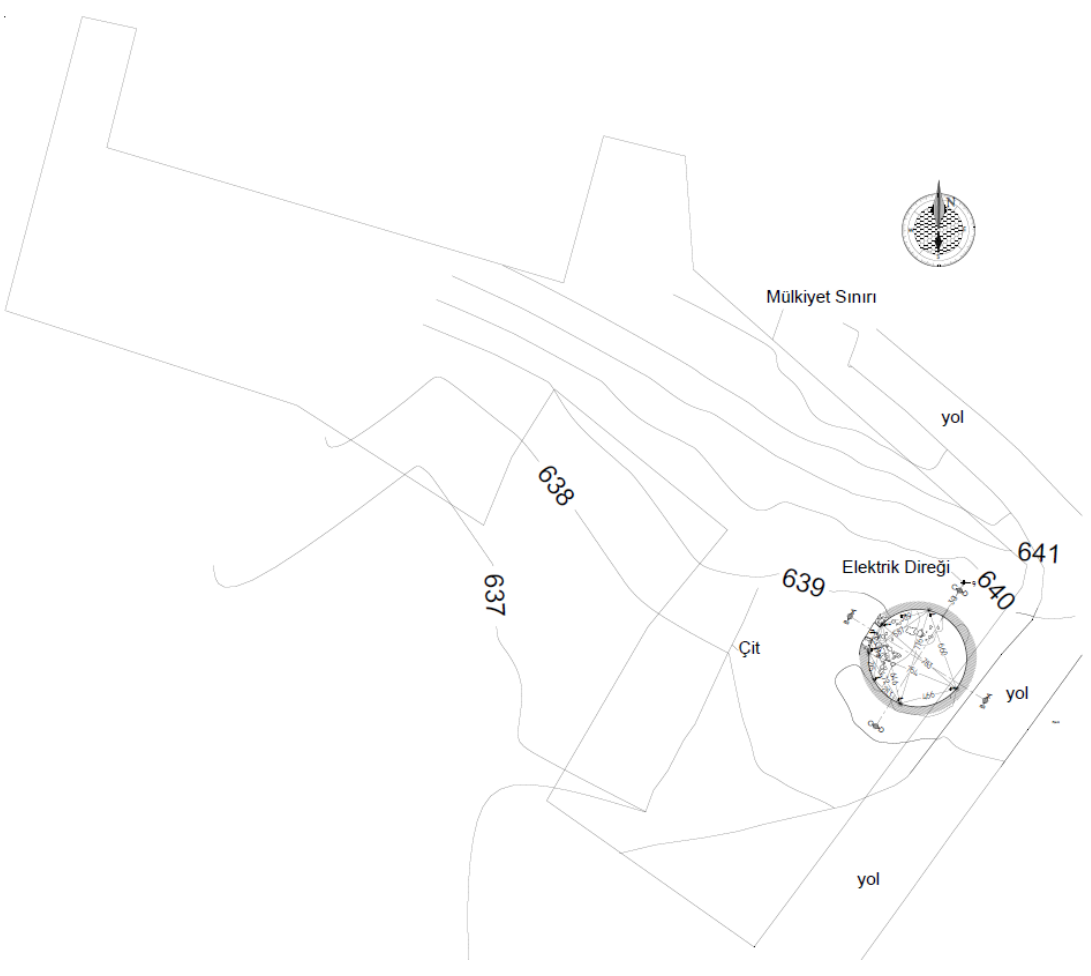

Şekil 10. Bozyer Sarnıcı, Rölöve Vaziyet Planı (Çizim M.E. Dere) [15]

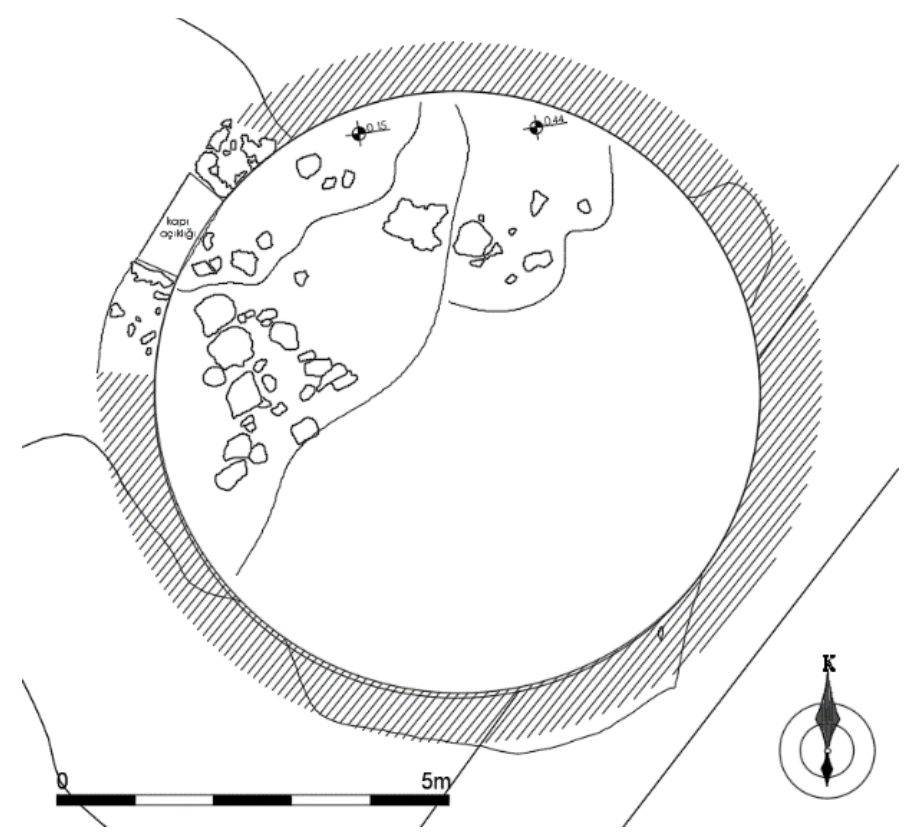

Şekil 11. Bozyer Sarnıcı Rölöve Planı (Çizim; M.E. Dere) [15]

\section{B. YAPININ TARİHI}

Muğla yöresi sarnıçların inşa tarihleri genel itibariyle 16 yy. tarihlendirilmektedir. Bu konuda Kunduracı; "Muğla ve çevresinde çok sık rastladığımız silindirik gövdeli, kubbe örtülü tarihi değere 
sahip gümbetlerin 16 yy.'da Kanuni Sultan Süleyman'ın Rodos seferi sirasında izlediği yol güzergahında yoğunlaştığı görülür. ” [16], şeklinde ifade etmektedir. Açıkgöz ise Bodrum yöresi sarnıç kitabelerinden hareketle 18 yy. [14] işaret etmektedir.

Alparslan Mahallesinde Bozyer Mevkiinde yer alan Bozyer Sarnıcının (Şekil 11) yapım tarihi kesin olarak bilinmemekle birlikte; yapım tekniği, üslubu plan düzenlemesi ve benzer yapılar itibariyle 18 . yüzyılda inşa edildiği tahmin edilmektedir [15]. Kunduracı Muğla'nın Yatağan yöresi sarnıçlarının inşa tarihi hakkında;

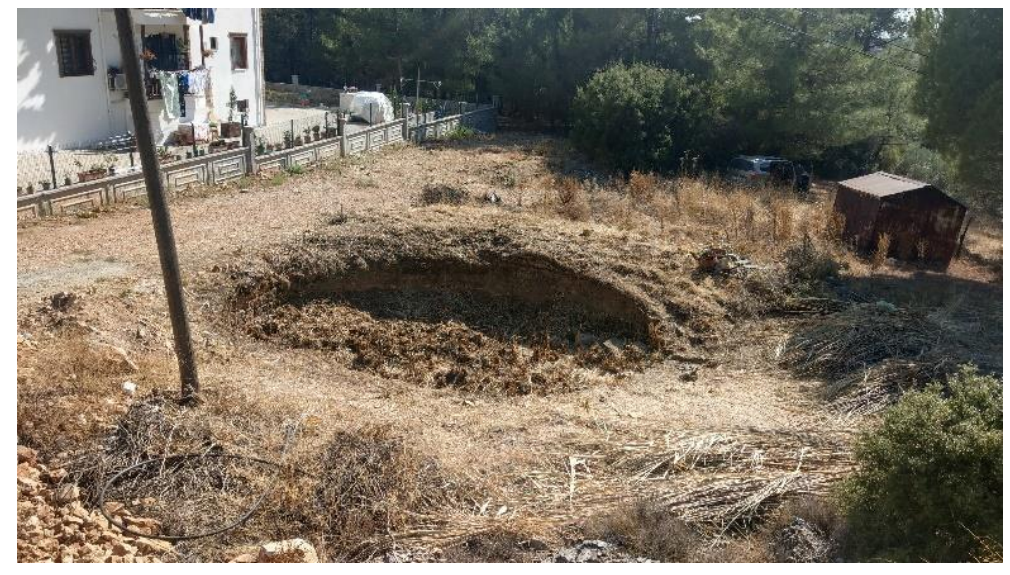

Şekil 12. Bozyer Sarnıcı (Fotoğraf; M.E. Dere)

Tescilli Bozyer Sarnıç yapısı inşasında kabayonu taş malzeme kullanılmıştır (Şekil 13). Eğimli bir araziye konumlanmış sarnıç (Şekil 12), "kısmi gömme" sarnıçlardan ve "gövdesi silindirik" olanlar grubuna girmektedir.

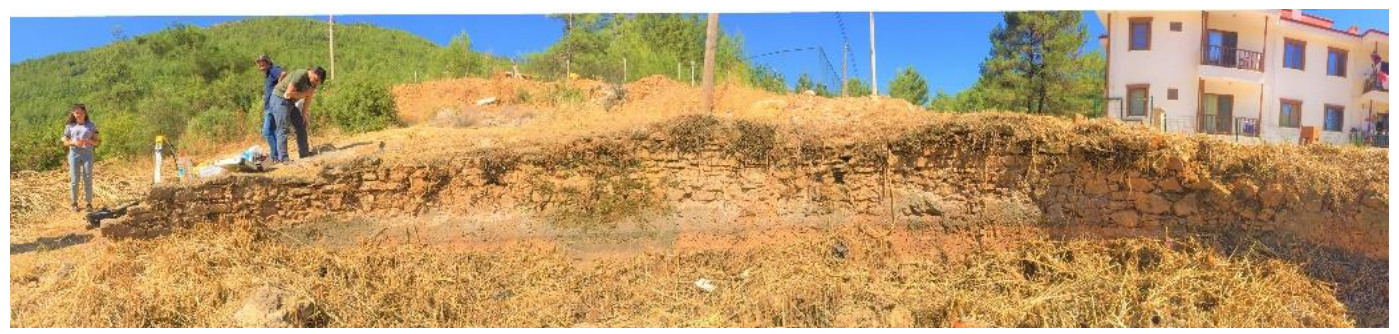

Şekil 13. Bozyer Sarnıcı iç hazneden görünüş (Fotoğraf; M.E. Dere)

Dairesel planlı Bozyer Sarnıcı tek bir mekândan oluşmaktadır. Yapı yaklaşık 7,80 m çapında olup yığma moloz taş tekniğinde inşa edilmiştir. Duvarları toprakla hemzemin olmuş beden duvarları haricindeki toprak üst duvarları ve çatı kubbesi yıkılmıştır. Yapının girişi kuzeybatı tarafındadır [15].

\section{BENZER SARNIÇ YAPILARININ KARȘILAȘTIRILMASI}

Çalışma konusu Bozyer Sarnıcı ile Yeşilova (eski Çaydere) ve Kızılcaekin mevkiindeki sarnıçların aynı yol güzergahları üzerinde bulunmaları ve yapım tekniği bakımından tipolojik benzerlikleri sebebiyle söz konusu sarnıçları aynı döneme tarihlendirilebilinir. Aynı plan örgütleriyle, yani dairesel planlı, kısmi gömme, savaklı ve kubbeli biçimleriyle benzer yapı özelliği göstermektedirler.

Çaydere Sarnıcı (Şekil 14); Ula İlçesi, Yeşilova Mahallesi, Çaydere Mevkii, 45 pafta, 79 ada, 40 parselde, köy meydanında yer alan Çaydere sarnıcı Ula'nın Alparslan, Elmalı ve Gökova mahallerini birbirine bağlayan kavşağa komşudur (Şekil 4). 
Kapı üzeri kitabesi vardır, fakat okunamamıştır (Şekil 15b). Sarnıç iç mekân çapı yaklaşık 7,50 m ve dış çapı yaklaşık 8,90 m'dir. Bozyer Sarnıcı ile yaklaşık aynı ebatlara haizdir. Sarnıç iç mekân çapı yaklaşı 7,50 m iken zeminden kubbeye mesafe de yaklaşı $5,50 \mathrm{~m}$ yüksekliktedir. Yani yaklaşık küre formundadır. Sarnıcın iç mekâna 7 basamaklı taştan merdivenle inilir (Şekil 15a). Çaydere sarnıcı da yarı gömme sarnıçlardan olup toprak altında yaklaşı 1,50 m derinliğe inmektedir.

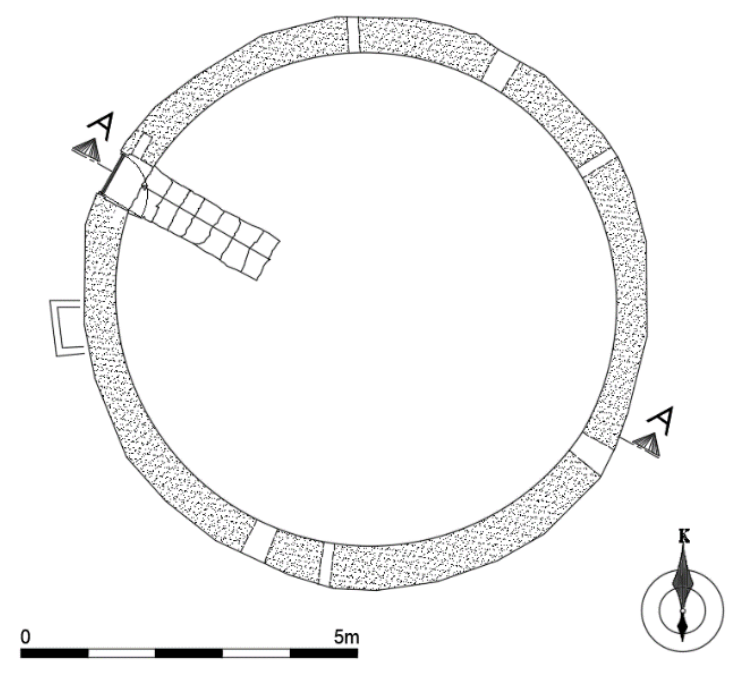

Şekil 14. Çaydere Sarnıç Planı (Çizim M.E. Dere) [15]

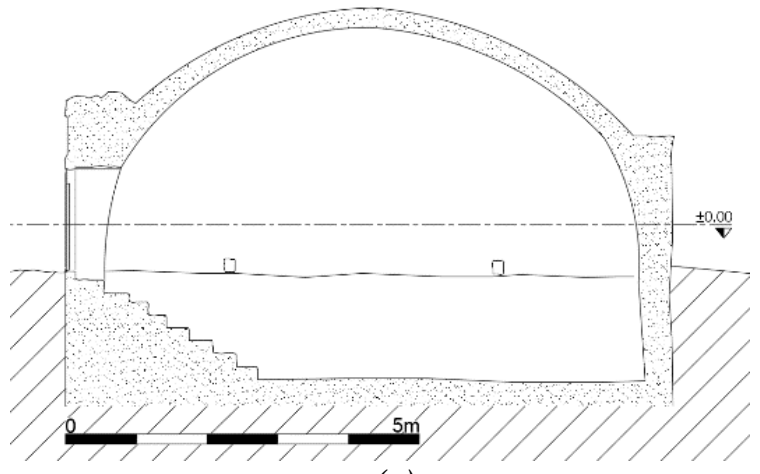

(a)

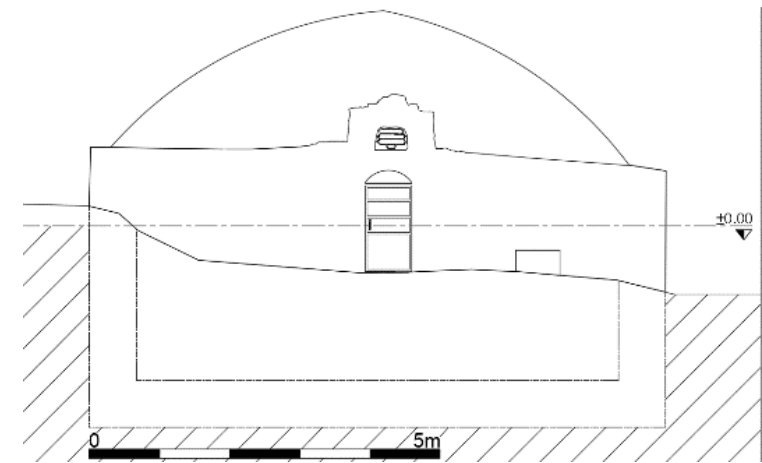

(b)

Şekil 15. Çaydere Sarnıcı; (a) A-A Kesiti, (b) Ön Görünüş (Çizim M.E. Dere) [15]

Kızılcaekin Sarnıc1; Ula İlçesi, Demirtaş Mahallesi, Kızılcaekin Mevkii, 35 pafta, 43 ada, 2 parseldedir. Bu sarnıç Ula ile eski Çaydere Köyünü (günümüzde Yeşilova mahallesi) bağlayan yol üzerindedir. Kapı üzeri kitabesi yoktur (Şekil 17a). Sarnıç iç mekân çapı yaklaşık $6,80 \mathrm{~m}$ ve dış çapı yaklaşık 8,15 m'dir (Şekil 16). Sarnıcın iç mekânına 6 basamaklı taştan merdivenle inilir (Şekil 17b). Bozyer Sarnıcından yaklaşık 1,00 m çapında daha küçüktür (Şekil:5). 


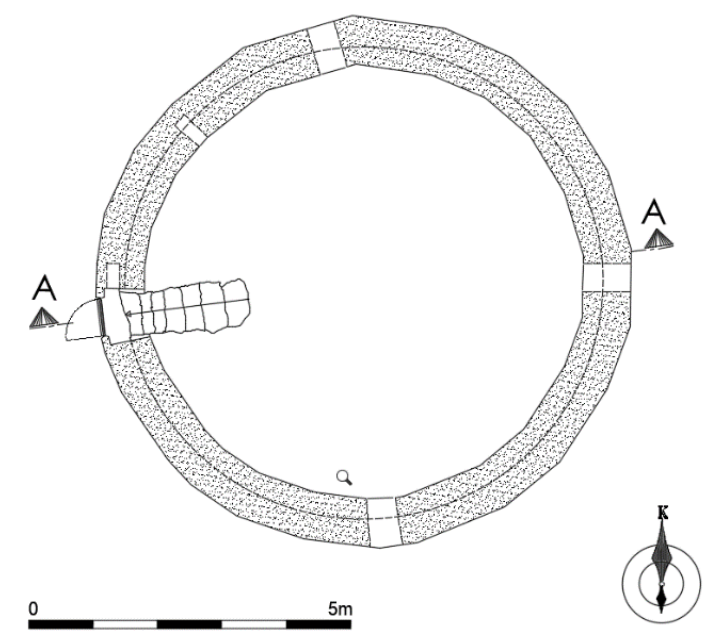

Şekil 16. Kızllcaekin Sarnıç Planı (Çizim M.E. Dere) [15]

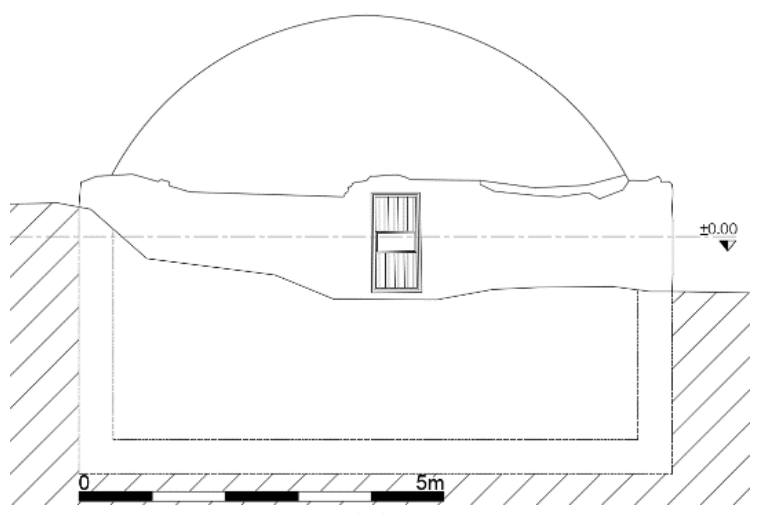

(a)

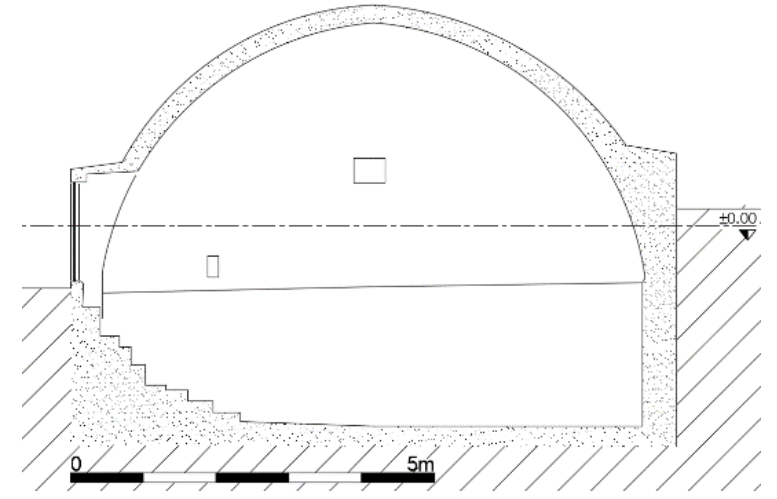

(b)

Şekil 17. (a) Kızllcaekin Sarnıcı Ön Görünüs,, (b) Kızılcaekin Sarnıcı A-A Kesiti (Çizim M.E. Dere) [15]

Sarnıç iç mekân çapı yaklaşık 6,80 m iken zeminden kubbeye mesafe 5,90 m yüksekliktedir. Yani yaklaşık küre formuna haizdir.

\section{BOZYER SARNICININ REKONSTRÜKSIYYON PROJESI}

Mülkiyeti Ula Belediyesi'nde olan ve yeşil alan içinde kalan Bozyer Sarnıcı projesi, Ula Belediye Başkanı ve teknik personelleriyle yapılan 24.08.2021 tarihli toplantıda söz konusu tarihi tescilli yapıya yüklenecek fonksiyon belirlenmiştir. Sarnıcın yer aldığ $1934,08 \mathrm{~m}^{2}$ lik yeşil alanın sarnıcın bulunduğu $830,00 \mathrm{~m}^{2}$ 'lik kısmı sanat ve sosyal etkinliklerin yürütüleceği "sanat evi” olarak işlev yüklenmiștir. Bu doğrultuda hazırlanan proje Muğla Kültür Varlıklarını Koruma Bölge Kurulu tarafından 23.09.2021 tarih ve 11465 sayılı karar1; "24.06.2005 tarih ve 951 sayll karartyla tescilli su sarnıcının rölöve, restitüsyon ve ilave yapılanmayı içeren rekonstrüksiyon" [15] ile onaylanmıştır.

Sarnıcın bulunduğu alanın kuzey, doğu ve güneyi yollarla çevrilidir. Söz konusu alanın kuzey-güney sınırları arasında yaklaşık 6,00 m'lik kot fark1 vardır (Şekil 18). Sarnıcın konumlandığı eğimli arazinin çevresi kot farklarına göre kademeli olarak ve her kademede babalarla birleştirilmiş taş duvarla sınırlandırılmıştır (Şekil 21). 


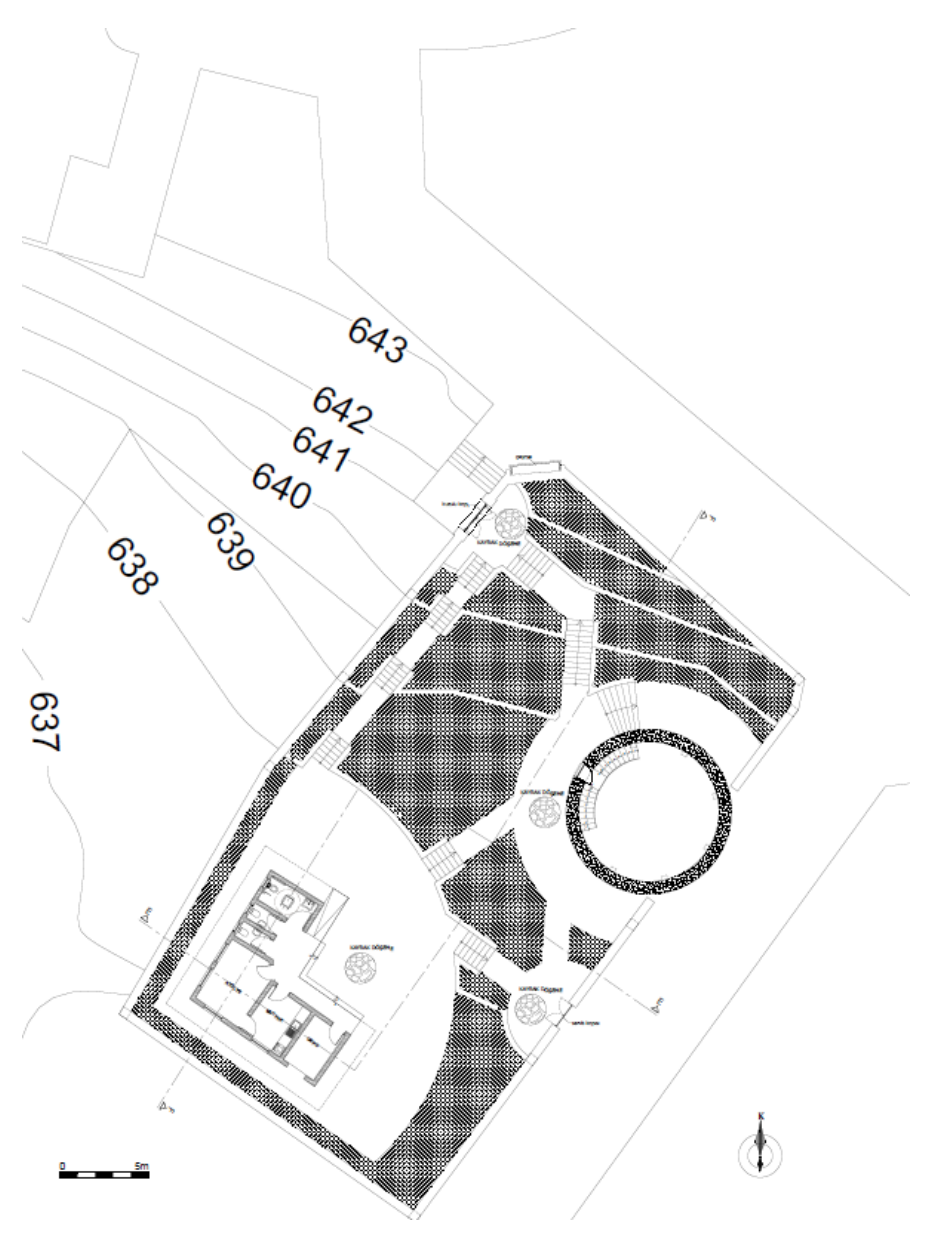

Şekil 18. Sarnıç Çevre Düzenlemesi ve Yerleşke Planı (Çizim M.E. Dere) [15]

Tanımlanan alanın, kuzey batı köşesine yöreye has kuzulu kapıdan (Şekil 22) ve güneybatı yönünde sarnıcın altından çift kanat demir ferforje kapıdan giriş sağlanmaktadır (Şekil 18). Ayrıca konu su mimarisi olduğundan tanımlı alanın kuzeybatı köşesine yörenin memba suyu olan Sandıras suyunun çeşmeden akıtılması için çeşme tasarlanmıştır (Şekil 19).

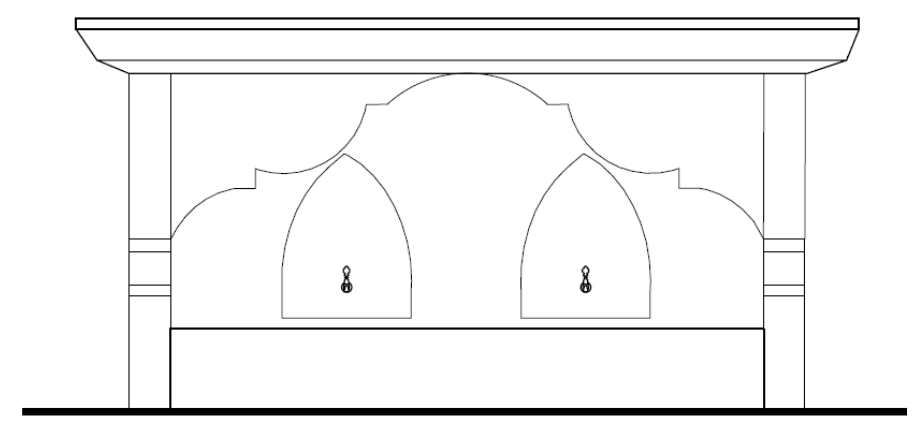

Şekil 19. Çeşme Ön Görünüş (Çizim M.E. Dere) [15] 


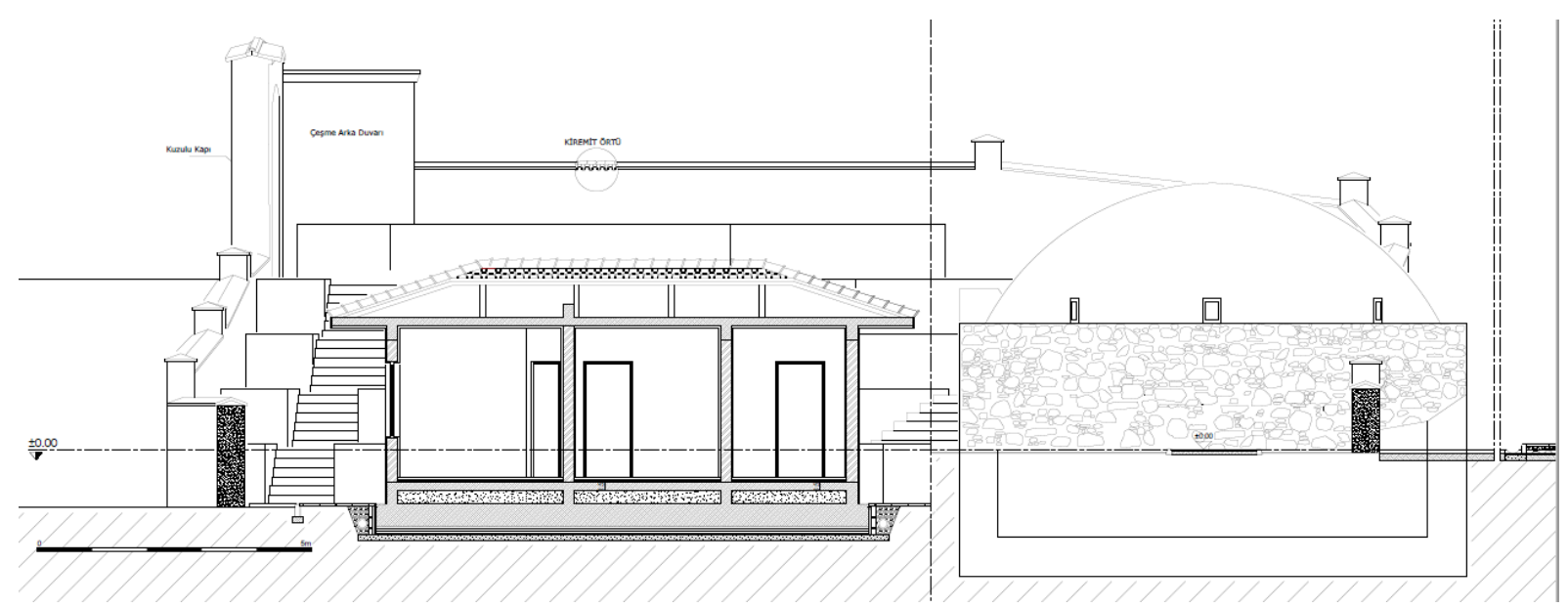

Şekil 20. E-E Kesiti (Çizim M.E. Dere) [15]

Arazi içindeki kot farkları korunmuş ve kademeler taş duvarla betimlenmiştir (Şekil 22). İki kademe arası oluşturulan düz satıh çimlendirilecektir (Şekil 21). Kot farkları arasında gerek sarnıç yapısına gerekse yeni tasarlanan müştemilata iki farklı merdiven güzergahından ulaşım sağlanması tasarlanmıştır (Şekil 20-21).

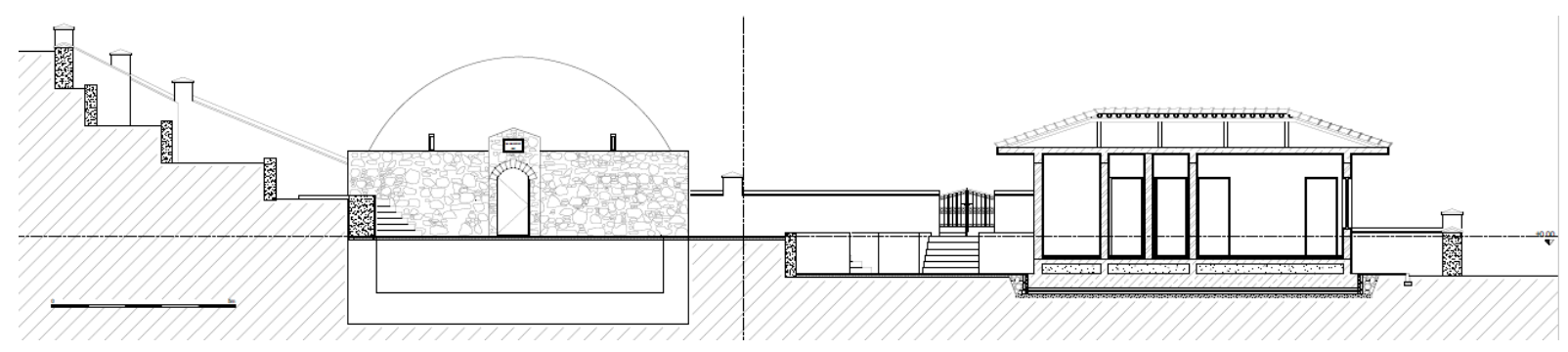

Şekil 21. F-F Kesiti (Çizim M.E. Dere) [15]

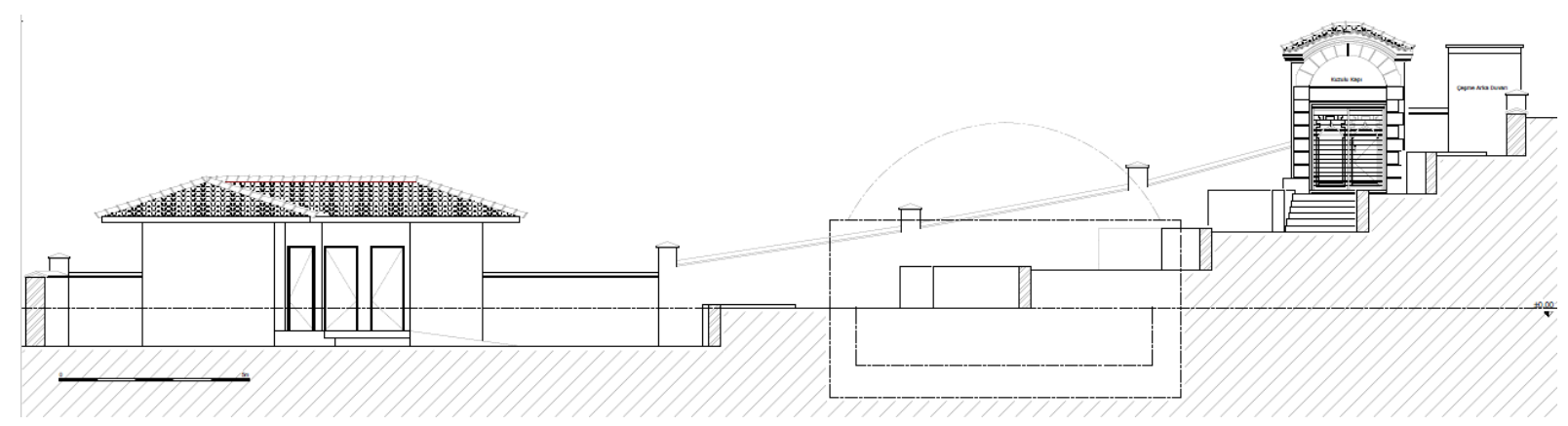

Şekil 22. Güneydoğu Görünü̧̈ü (Çizim M.E. Dere) [15] 


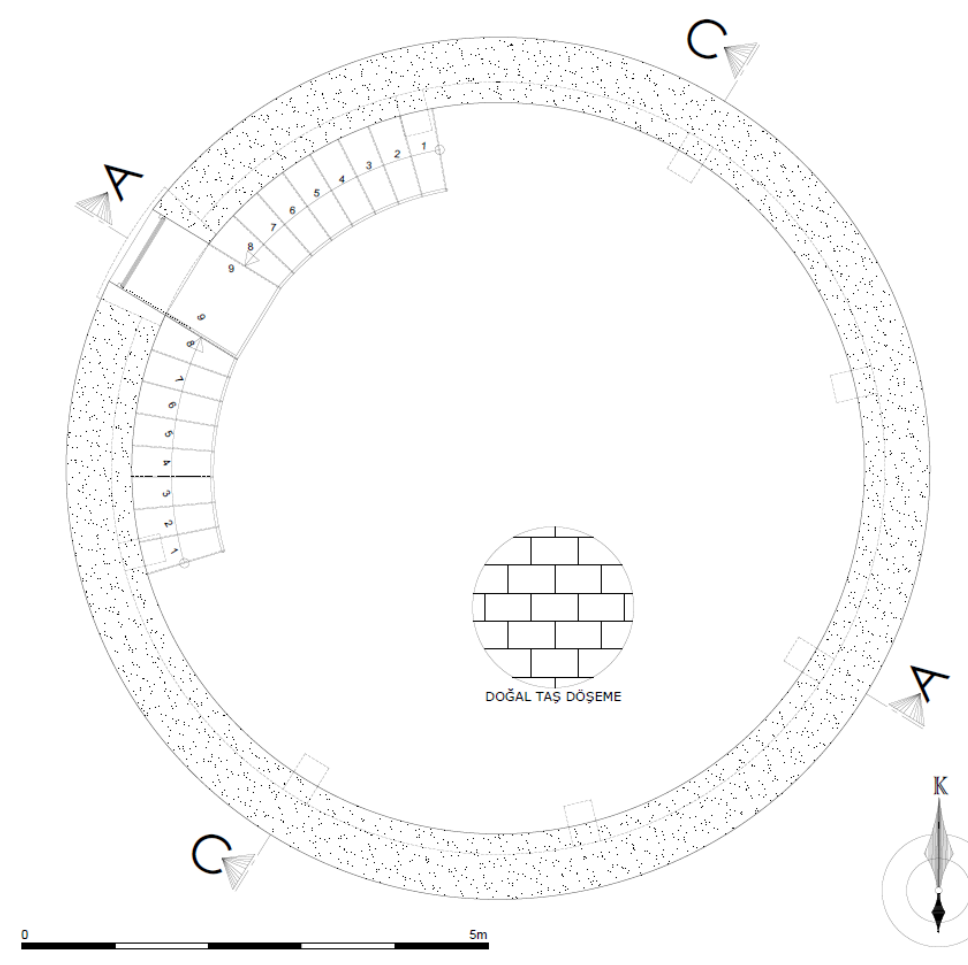

Şekil 23. Sarnıç Planı (Çizim M.E. Dere) [15]

Sarnıç yapısının mevcut beden duvarları sağlamlaştırıldıktan sonra Kurul onaylı projesine göre tamamlanacaktır. Sarnıcın iç mahaline sarnıç benden duvarlarına paralel çift kollu ahşap merdivenle ulaşımı sağlanacaktır (Şekil 23, 24a ve 24b). Bu yapıyı konu alan rekonstrüksiyon projesinin amacı; bu yapının özgün işlev ve tasarımına zıt olmayan amaçla korunması, malzeme, detay ve yapısal bütünlüğünün sağlanması ve işlevsel/yapısal sürdürülebilirliğinin oluşturulması ile kent hayatına entegrasyonu ve gelecek nesillere aktarımı hedeflenmiştir.

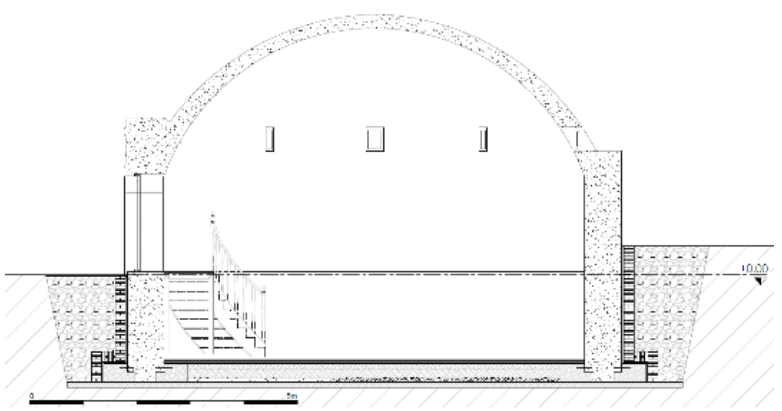

(a)

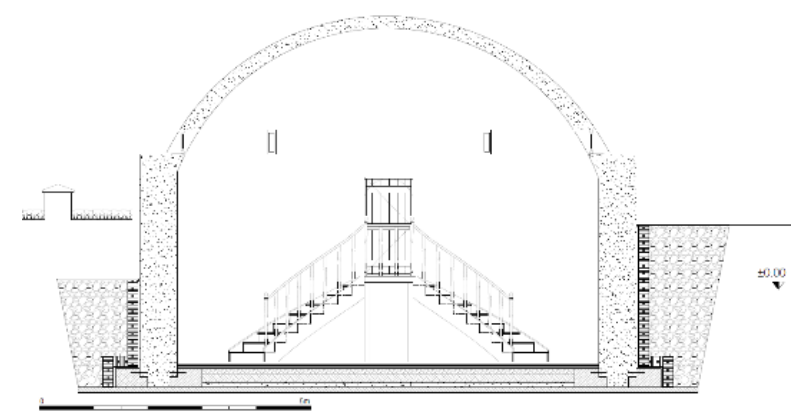

(b)

Şekil 24. (a) Kesit A-A, (b) Kesit C-C (Çizim M.E. Dere) [15]

Sarnıç, su mimarisinin ögelerinden olup gelecek nesillere aktarılacak mekânsal hafizanın deneyimlenmesinde önemli bir işlev yüklenecektir. Bunun yanında galeri işlevi görebileceği sanatsal etkinliklerin bir parçası olarak da kullanılabilecektir. Fakat sanatsal etkinlikler için ihtiyaç duyulan mekânsal büyüklüklere cevap veremeyeceğinden ek bir yapı tasarlanmıştır. Ek yapı yani müştemilat ahşap konstrüksiyonlu (Şekil 25) olup, içinde 1slak hacimler, sanat atölyesi, mutfak ve depoyu içinde barındıracak şekilde planlanmıştır. Bu müştemilat asal yapı olan sarnıcın siluetini etkilemeyecek şekilde arazinin en alt köşesine yerleştirilmiştir. Tescilli Bozyer Sarnıcı ile ihtiyaç duyulan diğer işlevlerin içinde barındırılan "L" formundaki müştemilat arasında bir meydan oluşturulmuş, (Şekil 18) böylelikle Sarnıç odak haline getirilmiştir [15]. 


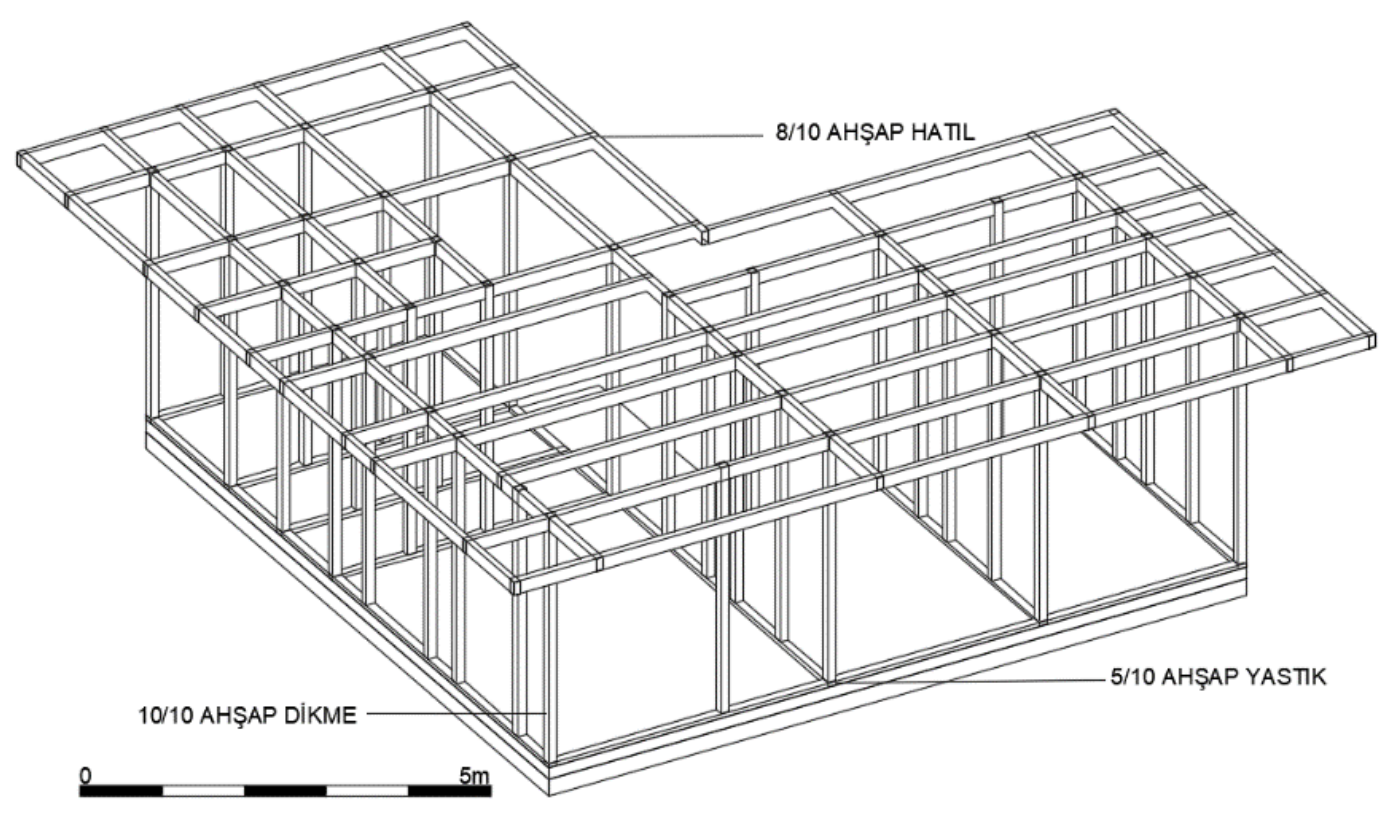

Şekil 25. Müştemilatın İzometrik Ahşap Konstrüksiyon Görünüşü (Çizim M.E. Dere) [15]

\section{IV.SONUC}

Yaşamın büyük ölçüde merkezinde yer alan su mimarisi her toplum tarafindan farklı sistem ve uygulama yöntemleri ile çeşitlilik göstermiş ve yine her toplum kendi benimsediği anlayışı doğrultusunda su yapıları inşa etmiştir. Zamanın bir getirisi olarak değişen yaşam şartlarıyla birlikte suyun yaşam alanlarına kolay ulaşması her geçen gün su mimarisinin yok olmasına yol açmıştır.

Su mimarisi Türk-İslam medeniyetinde önemli bir yer tutmaktadır. Suyu konu edinmiş, zorunluluğu işleve büründürmüş ve işlevi estetik değerlerle yüksek bir mimari forma dönüştürülmüş bu medeniyette zengin örneklerine sıklıkla rastlamak mümkündür. Çalışmada su mimarisinin bütüncül olarak ele alınarak tasnifi yapılmıştır. Bu tasnife göre Muğla ilinin Ula ilçesinde yer alan sarnıçlar incelenmiş ve detaylandırılarak kendi içinde tipolojilere ayrılmıştır.

Yaptığımız çalışmalar ve incelemeler sonrasında Ula ilçesindeki mevcut sarnıçlar dairesel formlu kısmi gömme sarnıçlar olup, çatı formlarına nispetle; sivri, kubbeli ve yüksek kubbeli olmak üzere üç farklı tipolojiye ayrılmıştır. Bu sarnıçların diğer bir ayırımı ise su haznelerinin suyla beslenmesine göre yapılmıştır. Bunlar; zemininden kapaklı ve çatı başlangıcında savaklı sarnıçlar şeklinde tasnif etmek mümkündür.

Projelendirilen Bozyer Sarnıcına sanat ve sosyal etkinliklerin yürütüleceği sanat evi işlevinin yüklenmesi, Ula ilçe merkezine artı değer katacaktır. Sarnıç, zaman içinde çeşitli sergilere ev sahipliği yaparak, ilçedeki sosyal etkinliklerinin odağı haline gelecektir. Zamanla ilkokuldan üniversite öğrencilerine, toplumun her katmanına hitap edecek bu yapının, mekânsal kurgusu ile geçmişte yaşayanların su ile iliş̧kisinin deneyimlenerek, anlaşılmasına katkı sağlayarak eğitsel bir işlev de görecektir. Ayrıca aynı parselde sarnıca saygılı ve mimari yapıyla bütünleşen müştemilatın sanat atölyesi olarak kullanımı mekânın sürekli kullanılarak, hayati fonksiyon kazanmasını sağlayacaktır.

Sonuç olarak, tescilli tarihi eser için restorasyona esas hazırlanan ve kurumlar tarafından onaylanan mimari projeler ve raporlar; yapıya ait restorasyon sürecinde izlenecek yolları, kullanılacak yöntemleri ve kaynakları açıklamak için düzenlenmiştir. Bu hazırlıkların amacı tarihi eserlerin özgün işlev ve başlangıç tasarımına zıt olmayan amaçla korunması; malzeme, detay ve yapısal bütünlügünün 
sağlanması ve işlevsel-yapısal sürdürülebilirliğinin oluşturulmasıyla gelecek nesillere aktarılması için yapılmıştır. Burada en önemli amaç, yapının özgün kimliğinden uzaklaştırılmadan yüklenen, aslına veya zamanın ruhuna uygun ama asıl işlevine ters olmayan fonksiyonu ile koruma ve kullanma dengesinin sağlanmasıyla restorasyonu sağlıklı bir şekilde tamamlamaktır. Bu ilkeler doğrultusunda hazırlanan projeler ile yapı kendi kaderine terk edilmişliğinden ve gün geçtikçe daha da tahrip olan, bakımsız ve harap halden kurtulması amaçlanmıştır. Restorasyonun tamamlanmasıyla da Türk-İslam Sanatına ve bu yöre toplumunun kültür hafizasına yeniden kazandırılarak, toplumsal hafızamızın mekânsal düzlemde kurgusu hem anlaşılacak hem de tarihi eserin yeni işleviyle kullanılarak korunması sağlanacaktır. Böylelikle yapının kaldırabildiği ölçüde zamanın ruhuna göre düzenlenmesi hem yapının yaşamasını hem de neslin tarihle bağ kurmasını sağlamış olacaktır.

\section{KAYNAKLAR}

[1] M. Esed, Kur'an Mesajı Meal-Tefsir, 5. baskı, İstanbul, Türkiye: İşaret Yayınları, 1999, ss. 1106-1217.

[2] Y. Önge, Türk Mimarisinde Selçuklu ve Osmanlı Dönemlerinde Su Yapıları, Ankara, Türkiye: Türk Tarih Kurumu Basımevi, 1997, ss. 1.

[3] C.E. Arseven, Türk Sanatı, 1. bask1, İstanbul, Türkiye: Cem Yayınevi, 1984, ss.96-102.

[4] N. Urfalığlu, "Sebil," Türkiye Diyanet Vakfi İslam Ansiklopedisi, 1. bask1, İstanbul, Türkiye: TDV İSAM Yayınları, 2009, c. 36, ss. 249-251.

[5] G. Kızılkayrak, Kadıköy Çeşmeleri; Kaynaktan Mahalleye Ab-ı Hayat, 1. bask1, İstanbul, Türkiye: Kadıköy Belediyesi, 2011, ss. 20.

[6] H. Ö. Barışta, İstanbul Çeşmeleri Azapkapı Saliha Sultan Çeşmesi, 1. baskı, Ankara, Türkiye: T.C. Kültür Bakanlığı Yayınları, 1995, Önsöz, ss. IX.

[7] S. Ökten, Aslında Bir Sanat Var, 1. bask1, İstanbul, Türkiye: Tuti Kitap, 2019, ss. 154.

[8] A. Kılc1, "Şadırvan," Türkiye Diyanet Vakfi İslam Ansiklopedisi, 1. baskı, İstanbul, Türkiye: TDV İSAM Yayılları, 2010, c. 38, ss. 220-221.

[9] S. Ünver, Y. Önge, "Selsebillerimiz,” Vakfflar Dergisi, s. XIII, ss. 339-374, 1967.

[10] M.B. Tanman, "Selsebil," Türkiye Diyanet Vakfi İslam Ansiklopedisi, 1. bask1, İstanbul, Türkiye: TDV İSAM Yayınları, 2009, c. 36, ss. 448- 449.

[11] N. Bozkurt, "Sarnıç," Türkiye Diyanet Vakfi İslam Ansiklopedisi, 1. baskı, İstanbul, Türkiye: TDV İSAM Yayınları, 2009, c. 36, ss. 158-159.

[12] Y. Önge, "Antalya yöresinde Türklerin yaptığı eski su sarnıçları," Arkitekt, s. 325, ss. 24-26, 1967.

[13] A. Ş. Duymaz, "Teke yöresi sarnıçları,” XIII. Ortaçă̆ ve Türk Dönemi Kazıları ve Sanat Tarihi Araştırmaları Sempozyumu, Denizli, 2009, ss. 225-234.

[14] N. Açıkgöz, "Muğla kır sarnıçları,” Muğla Kent Tarihi Dergisi, s. 1, ss. 19-20, 2005. 
[15] M. E. Dere, "Ula bozyer sarnıc1, rölöve, restitüsyon ve restorasyon projeleri ve raporları," T.C. Kültür ve Turizm Bakanlığı Kültür Varlıkları ve Müzeler Genel Müdürlüğü Muğla Kültür Varlıklarını Koruma Bölge Kurulu, Rap. 48.07.1353, 2021

[16] O. Kundurac1, Muğla-Yatağan Çevresindeki Türk Devri Mimarisi ve El Sanatlarl, 1. bask1, Muğla, Türkiye: Muğla Valiliği Kültür Yayını, 2007, ss. 63-72.

[17] Z. Eroğlu, Muğla Tarihi, 2. Bask1, Muğla, Türkiye: Muğla Belediyesi Kültür Yayınları, 2011, ss. 169.

[18] Milliyet Gazetesi. (2021, 21 Aralık). Muğla Haritası [Çevrimiçi]. Erişim: https://s.milimaj.com/others/image/harita/mugla-ili-haritasi.png.

[19] Anonim, "Ula bozyer sarnıcı,” T.C. Kültür ve Turizm Bakanlığı Kültür Varlıkları ve Müzeler Genel Müdürlüğü Muğla Kültür Varlıklarını Koruma Bölge Kurulu, Rap. 48.07.1353, 2005

[20] Tapu ve Kadastro Genel Müdürlüğü. (2021. 30 Ekim). Parsel Sorgulama Uygulaması [Çevrimiçi].

Erişim: https://parselsorgu.tkgm.gov.tr/\#ara/cografi/37.105976789633004/28.430978357791904. 